\title{
Services growth and convergence: Getting India's states together
}

\section{Anirudh Shingal}

\begin{abstract}
India's success story in services is well documented at the national level, but similar literature does not exist for India's states. In this paper, we bridge this gap in research by looking at India's services growth at the sub-national level and in doing so, also challenge existing literature by arguing that this growth has positive implications for income distribution. The first interesting finding is that even as per capita income is not converging across India's states, per capita services are and we provide evidence for this both in terms of traditional measures of sigma- and beta-convergence and more recent panel unit root tests. Secondly, not only is external demand an important determinant of services value added at the state level, but this demand also emanates from all over the country rather than being concentrated in the neighbouring or richer states. This suggests that the benefits from services growth are being distributed more widely than may be perceived.
\end{abstract}

JEL classification: C23, O11, O53, R11

Key words: Services, India, states, growth, convergence, demand

NCCR TRADE WORKING PAPERS are preliminary documents posted on the NCCR Trade Regulation website (<www.nccr-trade.org $>$ ) and widely circulated to stimulate discussion and critical comment. These papers have not been formally edited. Citations should refer to a "NCCR Trade Working Paper", with appropriate reference made to the author(s).

Research for this paper was funded by the Swiss National Science Foundation under a grant to the National Centre of Competence in Research on Trade Regulation, based at the World Trade Institute of the University of Bern, Switzerland. 


\title{
Services growth and convergence: Getting India's states together
}

\author{
Anirudh Shingal ${ }^{1}$
}

\begin{abstract}
India's success story in services is well documented at the national level, but similar literature does not exist for India's states. In this paper, we bridge this gap in research by looking at India's services growth at the sub-national level and in doing so, also challenge existing literature by arguing that this growth has positive implications for income distribution. The first interesting finding is that even as per capita income is not converging across India's states, per capita services are and we provide evidence for this both in terms of traditional measures of sigma- and beta-convergence and more recent panel unit root tests. Secondly, not only is external demand an important determinant of services value added at the state level, but this demand also emanates from all over the country rather than being concentrated in the neighbouring or richer states. This suggests that the benefits from services growth are being distributed more widely than may be perceived.
\end{abstract}

JEL classification: $\mathrm{C} 23, \mathrm{O} 11, \mathrm{O} 53, \mathrm{R} 11$

Key words: Services, India, states, growth, convergence, demand

\footnotetext{
${ }^{1}$ Senior Research Fellow, WTI, University of Bern \& Research Affiliate, CARIS, University of Sussex. The usual disclaimer applies. Address for correspondence: World Trade Institute, Hallerstrasse 6, CH - 3012, Bern; Email: anirudh.shingal@wti.org.
} 


\section{Table of Contents}

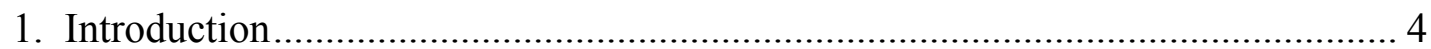

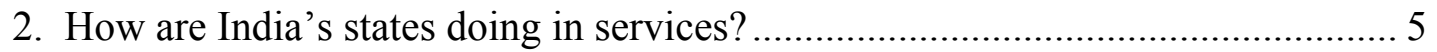

3. Does it matter? (Yes it does, read the services convergence story.).................... 8

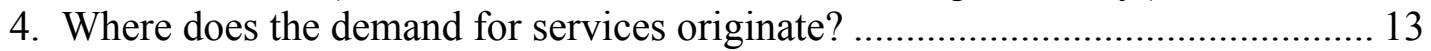

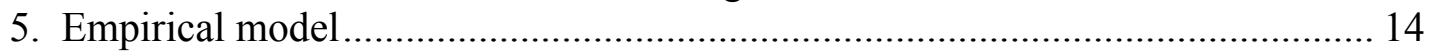

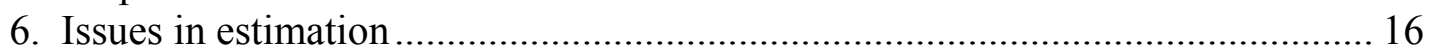

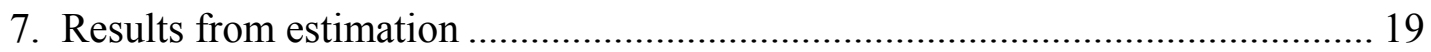

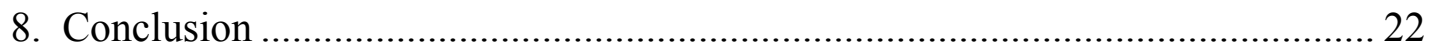

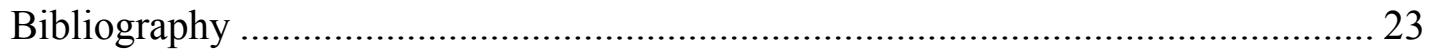

\section{$\underline{\text { List of figures and tables }}$}

Figure 1: Scatter plot of services share in GSDP against real PCY levels for major states

Table 1: A snapshot of India's states

Table 2: Sectoral breakdown of services contribution to GSDP and employment by

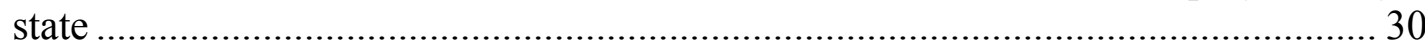

Table 3: List of variables, description and data source......................................... 31

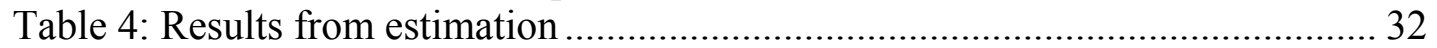

Table 5: The "neighbourhood" profile of Indian states ............................................ 33

Table 6: Decomposing external demand - from neighbours and rest of India........... 34

\section{$\underline{\text { List of annex tables }}$}

Table A1: Results from unit root tests on common factor and error ....................... 35

Table A2: Results from Breitung \& Das (2005) panel unit root tests ...................... 35

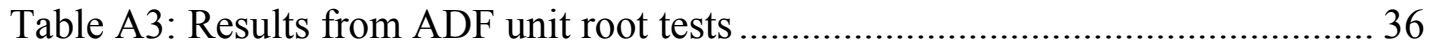

Table A4: Results from Johansen-Juselius (J-J) Cointegration Tests....................... 36 


\section{Introduction}

Services have emerged as the largest and fastest-growing sector globally in the last two decades. The sector contributes more than 60 per cent of global output and, in many countries, an even larger share of employment. This growth has also been accompanied by the rising share of services in world transactions, with services trade growing faster than goods trade in the period since 1990. There has also been a perceptible shift of FDI away from manufacturing towards services across the world. The share of services in total FDI stock in 2005 was around $61 \%$ compared to $49 \%$ in 1990 and only a quarter in the 70 s.

In line with this global trend, the services sector in India has also been witness to rapid growth, especially since the 1990s. In fact, this growth has now led to India becoming an "outlier" in terms of its services sector performance in the years since the turn of this century. Services contributed $52.6 \%$ of the country's GDP in 2006, which is higher than the share for countries at a comparable level of per capita income as India; the sector employed $32 \%$ of the country's labour force in 2004. Services exports accounted for 38.4\% of India's total exports in 2006 (against 20\% in 1990) and services trade was 15\% of the country's GDP in the same year (up from $3.4 \%$ in 1990).

India's services growth has generated a lot of interest among academics and practitioners and there has been considerable research trying to explain the "services revolution" in the country (for e.g. see Hansda, 2002; Gordon \& Gupta, 2003; Salgado, 2003; Banga, 2005; Verma, 2006; Eichengreen \& Gupta, 2010). However, the sustainability of services-led growth in India has been questioned (for e.g. see Mitra, 1988; Bhattacharya and Mitra, 1990 and Arunachalam \& Kumar, 2002). In particular, the lack of a concomitant increase in services employment has been pointed to as the inability of this growth process to draw people away from agriculture with associated implications for income distribution and convergence.

All these studies, however, look at the performance of services at the national level and to the best of our knowledge, there is not much literature exploring the services phenomenon at the sub-national or state level in India ${ }^{2}$. In this paper, we not only bridge this gap in research but also challenge existing literature by suggesting that services growth in India may be

\footnotetext{
${ }^{2}$ Some work has been done by Wu Yanrui (2004), Deepita Chakravarty (2005) and Amin \& Mattoo (2008).
} 
equalizing in the long run. To substantiate our claim, we employ both standard growth regressions from the convergence literature and more recent panel unit root tests to find that per capita services are converging across India's states, even as per capita incomes are not. In further investigative empirical analysis, we not only find external demand to be an important determinant of services value added in a number of states, but also find this demand to emanate from all over the country, thereby suggesting that the benefits from services growth are being distributed more widely than is perceived to be the case.

The rest of the paper is structured as follows. The next section provides a snapshot of India's state-level services performance as a starting point while Section 3 discusses why this is important in the context of results that suggest convergence in per capita services across the states. Sections 4 and 5 introduce and discuss the empirical model exploring the origin of demand for services at the state level. Section 6 discusses issues relevant for estimating our model while Section 7 looks at the results from estimation. Section 8 concludes.

\section{How are India's states doing in services?}

We begin by looking at the services ${ }^{3}$ performance of Indian states in terms of the sector's contribution to value added, employment and the associated growth rates in Table 1.

\section{$<$ Insert Table 1 here $>$}

At the outset, it may be worthwhile to point out that traditionally, 14 of the 28 Indian states have been regarded as "major" states based on their Gross State Domestic Product (GSDP), population, geographical size and location etc. These major states have been reported with an asterisk against their names in the tables in this paper. These states contribute 70 and $87 \%$ of India's GDP and population, respectively, which also means that hypotheses and results for the major states would also be broadly applicable to the whole of India. This is especially

\footnotetext{
${ }^{3}$ In terms of definition, the sector includes construction; utilities (electricity, gas and water supply); transport, storage and communication; trade; hotels \& restaurants; financial services; real estate and business services; public administration; and community, social and personal services.
} 
useful from a research perspective as data is not always readily available over a longer time period for the non-major states ${ }^{4}$.

Table 1 makes for a few interesting observations:

- Firstly, the importance of the services sector in GSDP across most Indian states (Services contribute at least half of the state domestic product in both the largest and the smallest states; the latter have also witnessed the highest growth rates in real services value-added)

- Secondly, the relative less importance of services share in employment across Indian states especially for the major as well as the services-intensive GSDP states (in fact the biggest services employers are the non-largest states)

- Thirdly, the growing importance of services overtime both in terms of GSDP and employment

- Fourthly, the growing importance of services overtime for the BIMARU ${ }^{5}$ states in general and Bihar in particular over the last decade, especially in GSDP and to a lesser extent in employment

- Fifthly, the top ten richest states (in terms of real per capita income or PCY) also have a higher share of services in GSDP and employment than the rest of the country

We next consider a more disaggregated analysis of services contribution to GSDP and employment across Indian states by sectors for the period 2000-07 by looking at percentage shares and growth rates in Table 2. To enable this analysis, we group the states into four categories: one, high PCY large states (MH, KR, TN, AP, KN, GJ, WB); two, low PCY large states (BH, UP, MP, RJ, OR); three, high PCY medium-sized states (PJ, HR); and four, nonmajor states.

\section{$<$ Insert Table 2 here $>$}

\footnotetext{
${ }^{4}$ These include the "seven sisters" from the North East (Arunachal Pradesh, Assam, Manipur, Meghalaya, Mizoram, Nagaland and Tripura), the small states of Jammu \& Kashmir, Goa, Sikkim and Himachal Pradesh, and the newly formed states of Chhattisgarh, Jharkhand and Uttaranchal (which were hived off from MP, Bihar and UP, respectively, in 2000-01).

${ }^{5}$ This is a collective term given to the historically poorly-performing states of Bihar, MP, Rajasthan and UP.
} 
In general, trade, hotels and restaurants; real estate and business; and construction services have been the traditional big contributors to services value added overtime across the majority of Indian states, so the structure has been fairly similar across space and time. The 90 s witnessed the importance of banking and insurance while communication services have gained significance in the years since 2000.

If we look at the percentage shares of services value added in Table 2, we see that (apart from $\mathrm{CH}, \mathrm{JH}$ and PJ) services contribute at least half of the GSDP in each state, irrespective of the level of per capita income, but there are sectoral fluctuations across states. For instance, mostly non-major states exhibit more than average shares in construction and utilities. Most of the high PCY large states show greater than average shares in communication; trade, hotels \& restaurants; real estate and business; and financial services. The low PCY large states, on the other hand, have above average shares in transport and trading services, the latter being true of PJ \& HR as well. Thus, there seems to be a clear demarcation with transport services especially railways driving demand in low income states; the higher income states focusing on communication, financial and other business services; and trade, hotels \& restaurant services showing importance across the board.

If we consider growth rates of services value added next and study states and sectors on the basis of "above" and "below" average growth rates, we see that, with the exception of other transport and real estate and business services where the low and high income states, respectively, show above-average growth, the four-fold classification of states by PCY and size does not work as well. For instance, in the case of construction services, UP, RJ as well as $\mathrm{MH}$, WB have experienced above-average growth. In the case of communication and financial services, both UP, OR and the high income states show above- average growth rates. Trading, hotel and restaurant services show UP, BH as well as the high income states with above-average growth rates. Thus, interestingly, when it comes to growth rates, one or the other low income state seem to be "catching-up" with the high income states across subsectors.

The disaggregated analysis of services contribution to employment across Indian states for the period post-2000 suggests that sectorally, trade/distribution, hotel \& restaurants and community, social and personal services have accounted for almost two-thirds of all workforce employed in services and the structure has been fairly similar across all states. 
Construction and transport, storage and communication services come next but the pecking order between them has varied across states. We also see a lot more variation in the share of services in total employment across states compared to that in value added. Also, sectoral variations in employment exist across states; sectors like utilities for instance employ very few people in all states. While no single sector emerges as an above-average employer across the low income states, transport, storage and communications; distribution, hotels and restaurants; and financial services show up as above-average employers across the high income states. In fact, all sectors are above-average employers in PJ and HR. For the nonmajor states, the big employers are construction, utilities, trading and community, social and personal services.

\section{Does it matter? (Yes it does, read the services convergence story.)}

The preceding section suggests that the states are performing well in services and while there are sectoral patterns in services demand and employment, growth itself is not restricted to particular states or sectors. But does this really matter? As mentioned above, the sustainability of services growth in India has been questioned in the literature; in particular, the services growth process is argued to have negative implications for income distribution and convergence.

We reviewed the literature studying income convergence across Indian states and found that accounting for differences in methodology, coverage of states and sample size, most studies have found significant income divergence across India's states [Nair (1971), Gupta (1973), Chaudhury (1974), Majumdar \& Kapoor (1980), Sarkar (1994), Dholakia (1994), Bajpai \& Sachs (1996), Marjit \& Mitra (1996), Ghosh et. al. (1998), Rao, Shand \& Kalirajan (1999), Dasgupta et. al. (2000), Kurian (2000), Aiyar (2001), Nagaraj et. al. (2002), Sachs et. al. (2002), Bandyopadhyay (2003), Gunji \& Nikaido (2004), Kocchar et. al. (2006), Kar \& Sakthivel (2007), Misra (2007), Kalra \& Sodsriwiboon (2010)] ${ }^{6}$. However, with the exception of Dasgupta et. al. (2000) and Kar \& Sakthivel ${ }^{7}$ (2007), none of these studies has

\footnotetext{
${ }^{6}$ A few have however documented the presence of conditional convergence [Aiyar (2001), Nagaraj et. al. (2002), Kocchar et. al. (2006), Purfield (2006), Misra (2007), Kalra \& Sodsriwiboon (2010)]. Cashin \& Sahay (1996) found absolute convergence but their results lacked statistical significance.

${ }^{7}$ Their analysis does not cover the period since 2000 and the authors show that regional inequality went up in the 90 s largely due to the rising inequality of industry and services in the period.
} 
looked at the sectoral pattern of GDP. Is it possible that any particular sector may in fact be showing evidence of convergence?

Using traditional measures of sigma- and beta-convergence from growth literature (Barro \& Sala-i-Martin, 1992, 1995), we tested our data for the presence of absolute convergence across the 14 major states $^{8}$ and as in the findings above, confirmed the absence of unconditional income convergence. However, interestingly, when we replicated this analysis at the sectoral level, we found evidence of absolute convergence in per capita services across the 14 major states.

The estimated $\beta$-convergence for per capita services value added for the 14 major states was 0.0096 (' $\mathrm{t}$ ' statistic $=-1.69$ ) over the period 1980-2006 and $-0.016(' \mathrm{t}$ ' statistic $=-1.93$ ) over the period $1990-2006^{9}$. Similar estimates of $\beta$-convergence for per capita income, albeit negative, did not report statistical significance over these time periods.

To calculate sigma-convergence in per capita services value added, we first computed the standard deviation in per capita services value added across states for each year and then estimated the trend in this standard deviation overtime. Looking at the major states again, we found the estimated trend to be -0.00003 over $1980-2006{ }^{10}$ (' $t$ ' statistic $=-0.03$ ) and -0.005 over $1990-2006^{11}$ (' $\mathrm{t}$ ' statistic $=-1.98$ ). Per capita income, on the other hand, exhibited sigma-divergence and statistically insignificant sigma-convergence, respectively, over these time periods.

Recent empirical literature, however, has criticised the use of traditional growth regressions in studying convergence [Friedman (1992), Quah (1993), Evans \& Karras (1996), Evans (1998), Temple (1999)] and advocated instead the use of non-stationary panel data econometrics [Quah (1994), Bernard \& Jones (1996), Evans \& Karras (1996)]. The latter consider the following data generating process:

\footnotetext{
${ }^{8}$ It is standard practice in this empirical literature to test for convergence across the major states as they account for a substantial share both of India's population and GDP.

${ }^{9}$ Sectorally, Indian agriculture also showed beta-convergence but only during 1990-2006; Indian industry showed divergence over both these time periods.

${ }^{10}$ Indian agriculture and industry both exhibited statistically insignificant sigma-convergence.

${ }^{11}$ Indian agriculture and industry also exhibited sigma-convergence.
} 
$\Delta x_{i t}=\mu_{i}+\rho x_{i, t-1}+\sum_{j=1}^{p} v_{i j} \Delta x_{i, t-j}+\varepsilon_{i t}$

where $x_{i t}=\log y_{i t}-(1 / N) \sum_{i} \log y_{i t}$ and $\varepsilon_{\mathrm{it}}$ is IID with mean $=0$.

The null hypothesis is $\mathrm{H}_{0}: \rho=0$, that is, all time series are random walks. Under the alternative, it is assumed that all the time series are stationary with $\mathrm{H}_{1}: \rho<0$. If the null of unit root is rejected, then $\mathrm{x}_{\mathrm{it}}$ would be mean reverting and any deviations from the cross-sectional average would diminish over time; hence the $y_{\text {it }}$ series would be converging ${ }^{12}$. On the other hand, if the unit root tests fail to reject the null hypothesis, then the evidence suggests that these deviations follow random paths thereby rejecting the convergence hypothesis. In a similar vein, we also decided to use panel unit root tests to test for convergence in per capita services.

Recent studies by O'Connell (1998) and Breitung and Das (2005) have highlighted that, in the presence of contemporaneous correlation, standard panel unit root tests like those proposed by Maddala and Wu (1999); Levin et al. (2002) and Im et al. (2003) suffer from severe oversize problem. We thus decided first to test our series for cross-sectional dependence and then decided to test them for convergence using different techniques from the literature suitable for our data and sample size.

Using the Modified Lagrange Multiplier test for cross-sectional dependence in Pesaran (2004), we found $\mathrm{x}_{\mathrm{it}}$ defined on per capita services to be cross-sectionally dependent. The estimated test statistic was 2.65 for the 14 major states over 1980-2006 (p value $=0.0079$; average absolute correlation $=0.372)$ and $5.77(\mathrm{p}$ value $=0.0000$; average absolute correlation $=0.615)$ over $1990-2006^{13}$.

If cross-sectional dependence is weak, literature suggests using robust panel unit root tests such as the one proposed by Breitung \& Das (2005). However, if cross-sectional dependence is strong, estimation requires decomposing the time series into common and idiosyncratic factors and testing them separately for the presence of unit roots (for e.g. Bai \& $\mathrm{Ng}, 2004$ ).

\footnotetext{
${ }^{12}$ In addition, if $\mu_{\mathrm{i}}=0$ then this convergence would be absolute.

${ }^{13}$ Similar results for $\mathrm{x}_{\mathrm{it}}$ defined on per capita income did not report statistically significant cross-sectional dependence.
} 
Unfortunately, however, there seems to be no consensus in literature on the definition of weak or strong dependence (Sarafidis \& Wansbeek, 2010) ${ }^{14}$.

In view of the above, the first method used to test for unit roots was the panel unit root test suggested by Breitung \& Das (2005) which is robust to weak cross-sectional dependence and also has power for small samples; this supported convergence in $\mathrm{x}_{\mathrm{it}}$ defined on per capita services but not on per capita income [the test statistic $\lambda^{*}$ for the 14 major states over 19802006 was $-1.895(\mathrm{p}$ value $=0.029)$ and $-1.24(\mathrm{p}$ value $=0.108)$ over 1990-2006; similar results for $\mathrm{x}_{\mathrm{it}}$ defined on per capita income lacked statistical significance].

Under the assumption of strong cross-sectional dependence, we next decided to estimate one common factor in $\mathrm{x}_{\mathrm{it}}$ defined on each of per capita income and per capita services using principal components analysis on their standardized first differences in line with the procedure outlined in Bai \& $\mathrm{Ng}(2004)^{15}$. As Bai \& Ng (2004) have further shown, the common factor estimated using principal components analysis and the idiosyncratic errors follow the standard Dickey-Fuller (DF) test (with and without intercept, respectively) under the null of unit root. We found both the common factor and the idiosyncratic error to conclusively reject the null of unit root in each case, irrespective of state coverage and sample size, thereby validating the convergence hypothesis. These results are reported in Annex Table A1.

However, in small samples with $\mathrm{N}$ and/or $\mathrm{T}$ less than 20 , such as ours, it is difficult to estimate the common factors and the number of factors accurately (Bai \& Ng, 2004; Sul, 2009). We thus decided next to use the cross-sectional demeaned version of the IPS test (CIPS) suggested by Pesaran (2005) which accounts for the dynamics in the common factor by using cross-sectional averages and their lagged values (without having to estimate the common factor first); the unit root test is based on the t-ratio of the OLS estimate of $\beta_{i}$ in the cross-sectionally augmented DF regression (CADF) below:

$$
\Delta x_{i t}=\alpha_{i}+\beta_{i} x_{i, t-1}+\gamma_{i} \bar{x}_{t-1}+\sum_{j=0}^{p} \delta_{i j} \Delta \bar{x}_{t-j}+\sum_{j=1}^{p} \eta_{i j} \Delta x_{i, t-j}+\varepsilon_{i t}
$$

\footnotetext{
${ }^{14}$ Pesaran (2005) considers an average correlation coefficient of 0.6 in the cross-section errors in his empirical investigations (op.cit. pp 25) as indicative of strong cross-sectional dependence. In comparison, our panel of 14 major states over 1980-2006 would seem to report weak cross-sectional dependence.

${ }^{15}$ Given the small sample size, the panel criterion developed in Bai \& Ng (2002) cannot be used here as $\mathrm{N}$ is too small for precise estimation of the number of common factors.
} 
where $p$ is the order of the AR error process ${ }^{16}$ and the CIPS test statistic is given by:

CIPS $=(1 / N) \sum_{i=1}^{N} C A D F_{i}$

The CIPS test loses power for $\mathrm{T}<20$ and we therefore used it to test for convergence across the 14 major states over 1980-2006. In contrast to the results from Bai \& Ng (2004) above, the null of unit root was not rejected by $\mathrm{x}_{\mathrm{it}}$ defined on either per capita services or per capita income thereby suggesting non-convergence in both per capita services and per capita income ${ }^{17}$. These findings were also supported by the covariate-recursive mean adjusted unit root test of Sul (2009) on the common factor ${ }^{18}$ in $\mathrm{x}_{\mathrm{it}}$ defined on both per capita services and per capita income for the 14 major states over both 1980-2006 and 1990-2006.

In sum, per capita income levels are not converging across India's states based on most empirical results reported above. However, per capita services are found to converge based on results from traditional growth regressions as well as panel unit root tests under the assumption of weak cross-sectional dependence. This finding suggests that the divergence in per capita income over 1980-2007 is linked more to the country's non-services sectors. To test this conjecture empirically, we regressed the standard deviation in log of per capita income across the 14 major states $\left(\sigma^{p c y}\right)$ on the cross-sectional means of the logs of per capita services $\left(\boldsymbol{p c s v s}^{\boldsymbol{m}}{ }_{t}\right)$, per capita non-services $\left(\boldsymbol{p c a g r}^{\boldsymbol{m}}{ }_{t}, \boldsymbol{p c i n d}^{\boldsymbol{m}}{ }_{t}\right)$ and other control variables ${ }^{19}$ over 1980-2007 and 1990-2007.

$\sigma^{p c y}{ }_{t}=\alpha+\beta_{1} \operatorname{pcsvs}^{m}{ }_{t}+\beta_{2} \operatorname{pcagr}^{m}{ }_{t}+\beta_{3} p c i n d^{m}{ }_{t}+\beta_{4} \operatorname{pop}^{m}{ }_{t}+\beta_{5} \operatorname{lib}^{m}{ }_{t}+\beta_{6} \operatorname{expd}_{t}{ }_{t}+\varepsilon_{t}$

We found per capita services to impact negatively and per capita industry to impact positively on the standard deviation in per capita income overtime ${ }^{20}$, thereby suggesting that Indian industry was driving the divergence in per capita income over these periods while services

\footnotetext{
${ }^{16}$ This was found to be one for $\mathrm{x}_{\mathrm{it}}$ defined on per capita services and two for $\mathrm{x}_{\mathrm{it}}$ defined on per capita income.

${ }^{17}$ The computed CIPS test statistics had values of -1.6 and -1.63 , respectively.

${ }^{18}$ As Sul (2009) has pointed out, if the null of unit root in the common factor is not rejected, then there is no need to test the hypothesis for the idiosyncratic factors ( $p$ p 2, op.cit).

${ }^{19}$ These included population $\left(\boldsymbol{p o p}^{\boldsymbol{m}}{ }_{t}\right)$, state-level openness index from Marjit et.al (2007) as a proxy for trade $\left(\boldsymbol{l i b}^{\boldsymbol{m}}{ }_{t}\right)$ and the share of developmental expenditure in GSDP $\left(\boldsymbol{\boldsymbol { e x p d } ^ { \boldsymbol { m } }}{ }_{t}\right)$. Unfortunately, data on state-level GFKF was not available for all states to be included as an explanatory variable in this equation. Data on $\boldsymbol{l i b}^{\boldsymbol{m}}{ }_{\boldsymbol{t}}$ was available from 1980 to 2002 and on $\operatorname{expd}^{\boldsymbol{m}}{ }_{t}$ from 1997 to 2007 only.

${ }^{20}$ Estimated $\beta_{1}$ was -0.34 over $1980-2007$ and -0.31 over $1990-2007$, with the respective ' $t$ ' statistics being -7.2 and -3.6. Estimated $\beta_{3}$ was 0.46 over 1980-2007 and 0.56 over 1990-2007, with the respective ' $t$ ' statistics being 4.1 and 3.4.
} 
had a dampening influence. Services growth can thus be the answer to India's income divergence in the long-run if this growth can offset the diverging impact of Indian industry building on the preponderance of the services sector in the country's GDP and its growing share in the labour force. What is more, this makes services growth more politically sustainable than has been hitherto made out. This is also corroborated by the result for Bihar, the poorest amongst the major states, showing up above the fitted trend line in the years since 1990 in a scatter plot of services share in GSDP against PCY levels for the 14 major states in Figure 1.

\section{<Insert Figure 1 here $>$}

\section{Where does the demand for services originate?}

So far we have documented the services growth in India at the sub-national level and also found evidence for this growth to be equalizing across India's states. But where is the demand for these services coming from?

If we assume for the sake of exposition that the entire GSDP of a state emanates from services, then using the fundamental macroeconomic identity, we have:

$\boldsymbol{Y}_{i t}{ }^{S} \equiv C_{i t}{ }^{S}+\boldsymbol{I}_{i t}{ }^{S}+G_{i t}{ }^{S}+\left(X_{i t}^{S}-M_{i t}{ }^{S}\right)$

wherein services output in state ' $i$ ' at time ' $\mathrm{t}$ ' $\left(\mathbf{Y}_{\mathrm{it}}^{\mathbf{S}}\right)$ can be decomposed into internal/domestic absorption of services $\left(\mathbf{C}_{\mathrm{it}}^{\mathbf{S}}+\mathbf{I}_{\mathrm{it}}^{\mathbf{S}}+\mathbf{G}_{\mathrm{it}}^{\mathbf{S}}\right)$ and net services exports $\left(\mathbf{X}_{\mathrm{it}}^{\mathbf{S}}-\mathbf{M}_{\mathrm{it}}{ }_{\mathrm{it}}^{\mathbf{S}}\right)$.

$\left(\mathbf{X}_{\mathbf{i t}}{ }^{\mathbf{S}}-\mathbf{M}_{\mathbf{i t}}{ }^{\mathbf{S}}\right)$ can also be looked at as the net consumption, investment and government demand for a state's services output originating outside the domestic boundary of the state. We can thus also look at this identity as:

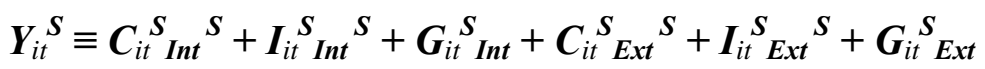

where 'Int' is internal demand and includes both the state's domestic absorption and demand for imports while 'Ext' is external demand or demand for exports. 
In a similar vein, we can decompose demand for services into internal (intra-state) and external (extra-state but intra-India) demand to examine its origin. Our empirical model is a slight modification of the traditional Heston, Summers \& Kravis (1983) equation which was used to determine whether services were income-elastic overtime. Instead of using countries, we consider Indian states and use an internal demand variable, which is nothing but the level of per capita income in each state. In addition, we look at the impact of income in the rest of the country - external demand - on the demand for services in a state. Moreover, in a secondary estimation, we decompose this external demand into that emanating from neighbouring states and from the rest of India, to examine if this demand is concentrated in the rich, neighbouring states or emanates from all over the country.

\section{Empirical model}

Using state-level data over 1980-2006, we regress services output on internal demand (defined as the state's per capita income), external demand (India's GDP minus the concerned state's GDP) and other control variables. The empirical model takes the following form:

pcsvs $_{i t}=\alpha_{i}+\beta_{1}$ TREND $_{t}+\beta_{2 i p c i n t e r n a l d d}$ it $-1+\beta_{3 i p c e x t e r n a l d d}$ it $-1+\beta_{4 i}$ lib $_{i t}+\beta_{5 i} u r b_{i t}+$

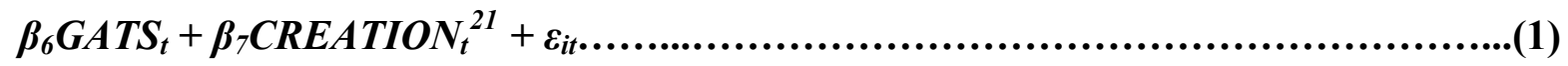

where all economic data is in real values and all variables in lower case are in log terms. The variable description and source are provided in Table 3.

\section{$<$ Insert Table 3 here $>$}

Given that internal demand is the sum of agriculture, industry and services value added, our model is likely to suffer from problems of endogeneity emanating from reverse causality. To mitigate this, we lag our explanatory internal and external demand variables by one period to

\footnotetext{
${ }^{21}$ The three new states of Chhattisgarh, Jharkhand and Uttaranchal came into existence in 2000 and were hived off from MP, Bihar and UP, respectively. The data for the latter three states from 2000-01 onwards therefore account for this change in territory. In our empirical analysis, we control for this change by including a dummy for the year 2000-01 for Bihar, MP and UP.
} 
nullify the impact of services value added in the reverse direction. This has two additional advantages. Firstly, it takes account of any autocorrelation that may be present in our time series as we are effectively using a lagged dependent variable on the RHS. Secondly, it makes use of the augmented demand model wherein services output in period 't-1' has an impact on services output in period 't.'

A priori, we expect the estimates of $\beta_{1}$ through $\beta_{6}$ to be positive.

The economic intuition for demand for services emanating from the output generated within the state is reasonably clear. As a state's economy improves, the need for greater and better quality services would tend to go up domestically.

Externally, the rise in demand for services emanating from rising extra-state income levels would tend to manifest itself in a rise in the state's services exports.

There are powerful forces at work in modern economies, some on the supply side, that imply actual shifts in the goods-services composition of output and employment. Some of these forces are demographic, for example, women's greater presence in the work force (which has an impact on the demand for household services), aging population (which increases the demand for health services), urbanization and/or suburban sprawl (which raises the demand for utilities). Given that most supply-side variables would be collinear with each other in such estimation, we only use urbanization as an explanatory variable in our model to proxy for such forces.

The shift to services may also be driven by public preferences for example, economic policies that reduce the rate of domestic investment in plant and equipment per unit of GDP such as deregulation, privatization and defense down-sizing. Arguably, the most powerful forces are knowledge-related. Advances in computer and communications technology, for example, have permanently increased demand for a wide range of communication services, revolutionized financial services and triggered explosive growth in the computer software industry. The effect of technological change is particularly evident in the production process itself through splintering. Technological change is also capital-embodied and as such, a rise in capital imports and FDI also has implications for the demand for services. We hope to capture all such factors through the trend variable. 
Last, but not the least, is the impact of state-specific liberalization and domestic economywide policy reform vis-à-vis the services sector, which we hope to capture through the LIB index values and the GATS dummy.

\section{Issues in estimation}

The choice of the empirical strategy is governed by the underlying theory, data and its characteristics, recent developments in estimation methodology and any other objective(s) that the researcher may have.

Data was not consistently available for all the variables in our model across all states over 1980-2006. The maximum number of observations per variable for a major state was 27 while that for a non-major state was between 11 and 14. Data was generally not available for the states from the North East during the $80 \mathrm{~s}$ while the three newly formed states of Chattisgarh, Jharkhand and Uttaranchal came about only in 2000-01. Thus, constraints of data availability meant that estimation could be undertaken for the 14 major states only over 1980-2006.

Given the small size of our sample, it became imperative that we exploited the variation across both $\mathrm{N}$ and $\mathrm{T}$; the model specification meant that we were dealing with a dynamic heterogeneous panel which would need to be tested for both stationarity and cross-sectional dependence before deciding on the estimation technique. But most importantly, we were interested in getting the estimation output for each $\mathrm{N}$, which meant that the number of regressors would be 60 even in a simple OLS panel estimation. This had implications for the degrees of freedom available for model estimation, even more so if we needed to account for non-stationarity and cross-sectional dependence.

We began by testing our empirical model for cross-sectional dependence using the Modified Lagrange Multiplier test in Pesaran (2004) and found the null of cross-sectional independence to be decisively rejected (the estimated test statistic was $4.8 ; \mathrm{p}$ value $=0.0000$; average absolute correlation $=0.226$ ). Testing for the presence of unit root next, using the panel unit 
root test suggested by Breitung \& Das (2005), we found all our series to be non-stationary ${ }^{22}$. The results from the test are reported in Annex Table A2 ${ }^{23}$. These results meant that in panel estimation, we would need to account for both non-stationarity and cross-sectional dependence.

Recent literature on the estimation of dynamic heterogeneous non-stationary panels with cross-sectional dependence deals only with large samples [for instance see Pesaran (2003, 2006), Sarafidis (2007), Eberhardt \& Bond (2009), Sarafidis \& Robertson (2009), Bai (2010), Chudik et. al. (2010), Kapetanios, et. al. (2010), Pesaran \& Tosetti (2010), Robertson et. al. (2010), Sarafidis \& Wansbeek (2010)]. Even in the case of Pesaran (2006), Eberhardt \& Bond (2009) and Chudik et. al. (2010), where the small sample properties of the estimators have been investigated using Monte Carlo experiments, the minimum size of $\mathrm{N}$ and $\mathrm{T}$ considered is 20 , which still exceeds our sample size. These estimation techniques would thus not be strictly applicable to our sample; moreover using them could either result in statistically insignificant estimates or in non-estimation. In fact, our attempts at using the estimation techniques in Pesaran ${ }^{24}$ (2006) and Eberhardt \& Bond ${ }^{25}$ (2009) confirmed this intuition.

However, Pesaran (2006) notes that "In the case of panel data models where the cross section dimension $(\mathrm{N})$ is small (typically $\mathrm{N}<10$ ) and the time series dimension $(\mathrm{T})$ is large the standard approach is to treat the equations from the different cross section units as a system of seemingly unrelated regression equations (SURE) and then estimate the system by the Generalized Least Squares (GLS) techniques. This approach allows for general (timeinvariant) correlation patterns across the errors in the different cross section equations ${ }^{26}$."

\footnotetext{
${ }^{22}$ Only the log of lib rejected the null of unit root at the $10 \%$ level of significance.

${ }^{23}$ We also carried out Augmented Dickey- Fuller (ADF) unit root tests on each of the series for each state separately to check them for stationarity. The results of these tests are included in Annex Table A3. We found the log of per capita services value added to be I(1) across all states (except West Bengal where it was I(2)). The lagged log values of our per capita demand variables were also largely non-stationary across states except in Andhra Pradesh and Punjab, where both internal demand and that emanating from neighbouring states were found to be stationary. Log of urbanization was also non-stationary in most states barring Andhra Pradesh, Kerala, MP and Orissa. Finally, the log of our liberalization index was found to be stationary in more than half of the states.

${ }^{24}$ Pesaran's CCE estimators are based on an augmented regression model that includes the cross-sectional means of the dependent and independent variables on the RHS. Moreover, these estimators can be used irrespective of the order of integration of the underlying data (Kapetanios et. al., 2010).

${ }^{25}$ This involved a standard OLS estimation in first differences together with (T-1) time dummies in first differences in the first stage and then using the year dummy coefficients from the first stage regression in each of the $\mathrm{N}$ standard regressions in the second stage (this also includes a linear trend).

${ }^{26}$ Pesaran (2006) op.cit, pp1
} 
In light of the above, we decided to estimate our model using the dynamic feasible GLS (DGLS) of Moon \& Perron (2004) which involves estimating an augmented dynamic regression model that includes the leads and lags of the first differences of the regressors on the RHS and is estimated using feasible GLS. This technique was found suitable for estimating a SUR model with integrated regressors, comprising $\mathrm{N}$ individual linear cointegrating regression equations such as ours ${ }^{27}$. The authors also found the DGLS estimator to be asymptotically more efficient than the dynamic OLS estimator. Moreover, using feasible GLS, we could control for both cross-sectional correlation and heteroskedasticity across panels and within-panel AR(1) serial correlation.

The model was thus estimated in a panel by interacting the four cross-section varying explanatory variables with $(\mathrm{N}-1)$ state dummies together with the first ${ }^{28}$ lead and lag of the first differences of all regressors as below:

$y_{i t}=\alpha_{i}^{\prime}+\sum_{j=1}^{k^{\prime}} \beta^{\prime} x_{i j t}^{\prime}+\alpha_{i} D_{i}+\sum_{j=1}^{k} \beta_{i j} x_{i j t}+\sum_{j=1}^{k} \beta_{i j} \sum_{i=2}^{N} \sum_{j=1}^{k} D_{i} x_{i j t}+\sum_{l=-1}^{1} v_{l}^{\prime} \Delta x_{i, t-l}^{\prime}+\sum_{l=-1}^{1} \sum_{i=2}^{N} v_{i l} D_{i} \Delta x_{i, t-l}+\varepsilon_{i t}$

where $y$ is the dependent variable; $x^{\prime}$ refer to the state-invariant explanatory variables $\left(\mathrm{k}^{\prime}=3\right) ; D_{i}$ refers to the $(\mathrm{N}-1)$ state dummies; $x$ refers to the state-varying explanatory variables $(\mathrm{k}=4) ; \sum_{l=-1}^{1} v_{l}^{\prime} \Delta x_{i, t-l}^{\prime}+\sum_{l=-1}^{1} \sum_{i=2}^{N} v_{i l} D_{i} \Delta x_{i, t-l}$ are the leads and lags of the first differences of the state-invariant and state-varying explanatory variables, respectively; and $\varepsilon$ is the error term.

A preliminary examination of the data also revealed the existence of multicollinearity emanating especially from the three state-invariant explanatory variables. In addition to estimating the model on the original data, to improve the precision of our estimates, we also used factor analysis to orthogonalise the correlated regressors; this generated a single factor,

\footnotetext{
${ }^{27}$ We tested the $\mathrm{N}$ individual regression equations for cointegration using the Johansen-Juselius (1988, 1990, 1991, 1992, 1994) cointegration tests. The results from this, reported in Annex Table A4, validate the presence of at least two cointegrating relationships among our variables, significant at $5 \%$ and $1 \%$, across states, thereby indicating more stability in the system. We also tested the residuals from the cointegrating equations for stationarity and found the residuals to be stationary, which validated the cointegrating equation in each case.

${ }^{28}$ The number of leads and lags is close to $\mathrm{T}^{\wedge}(1 / 3)$. The size of our sample however meant that we could include only one lead and lag.
} 
which was used instead of the correlated regressors while estimating the model. As a robustness check, we also mean-centered the explanatory variables and estimated the model separately to get a third set of results.

\section{Results from estimation}

Table 4 reports the results from estimating the model using DGLS on both the original and transformed data.

\section{$<$ Insert Table 4 here $>$}

Focusing first on the estimated internal demand elasticities, we found services in AP, BH and MP to be predominantly internal-demand driven (estimated elasticities were the largest in magnitude, statistically significant and the ratio of external-to-internal demand in the last column of Table 4 was well below unity) in all results. Additionally PJ, TN, UP and WB also reported large internal demand elasticities but these were not always statistically significant. Internal demand for services was also strong in $\mathrm{MH}$ but perhaps not as much as external demand. Most of these states are large and services-intensive economies and with the exception of UP, MP and Bihar, rich as well, all of which seems to drive these results.

Looking next at the estimates of external demand elasticities, we find these to be large and statistically significant in $\mathrm{HR}, \mathrm{OR}, \mathrm{KN}$ and $\mathrm{KR}$ (also exceeding internal demand in most results). HR is adjacent to the National Capital Region ("NCR") of Delhi, which possibly accounts for the importance of external demand while both $\mathrm{KN}$ and $\mathrm{KR}$ are surrounded by states which are amongst the richest in the country. These results may thus point to the importance of having rich neighbours, a hypothesis that we further tested in a secondary estimation below.

Urbanization was found to be a strong and statistically significant explanatory variable of per capita services value added in most states thus negating any regional bias (though the negative sign on the estimated coefficient was a perverse result, possibly explained by the correlation of this variable with internal demand). The estimated coefficient on the liberalization variable was found to be statistically significant in most of our results and small 
in magnitude; the negative sign in a few cases could be due to the collinearity emanating from the way this variable has been calibrated by Marjit et.al. (2007) ${ }^{29}$. Creation and the GATS dummies lacked statistical significance in our results while the estimated trend was highly significant with a magnitude of $1.7-1.9 \%(p$-value $=0)$.

Interestingly, when we conducted a statistical test (chi-squared) of the ratio of external and internal demand being unity (results reported in the penultimate column of Table 4), we found this hypothesis to be rejected by at least half the states (AP, BH, HR, KN, KR, MH and OR always rejected the null of unity). In four of these states (HR, KN, KR, OR), the ratio exceeded unity while in two others (AP and $\mathrm{BH}$ ), internal demand seemed to be the more important determinant of services. The results for $\mathrm{MH}$, however, were inconclusive.

To probe further into what drives these results, a more interesting take on external demand involved segregating it between demand emanating from neighbouring states and that from the rest of the country to examine if this demand is concentrated in a few states or spread throughout the country. The motivation for this also came from Table 5 that lists Indian states, the number and names of states each state is contiguous with and the associated per capita income. We further hypothesized that having rich neighbours should have a large and significant impact on the services demand of each state and the greater is the number of such neighbours, the larger should such impact be.

\section{$<$ Insert Table 5 here $>$}

To test this conjecture, we carried out a secondary regression distilling the impact of external demand into that emanating from neighbouring states (pcneighdd) and the rest of the country (pcrestdd), with the other control variables remaining the same as in the primary estimation.

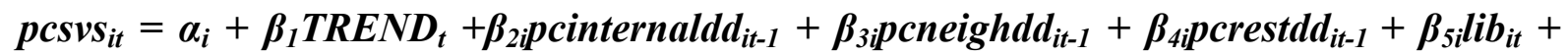

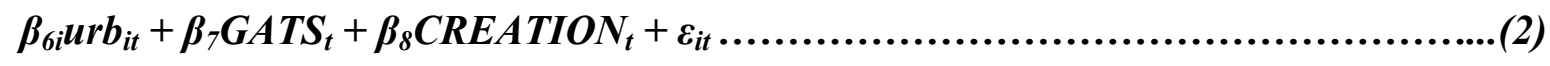

\footnotetext{
${ }^{29}$ The authors link the level of output of a specific state to all-India trade figures to get an approximate indicator of how much 'open' it is. If for a specific state most of the production is concentrated in items that contribute largely to export value at the all-India level, then it is reasonable to conclude that the particular state is attuned to exports. Similarly, if a state has high production value of import substitutes, then it must be relying less on imports and hence is not so open.
} 
The results from this secondary estimation are reported in Table 6.

\section{$<$ Insert Table 6 here $>$}

The first interesting observation is that demand from neighbouring states is a statistically insignificant determinant of services value added in almost all states and is also associated with negative elasticities. The exception to this is WB, where the demand from neighbouring states is positive and statistically significant and also more important than the demand originating in the rest of India (the ratio of the absolute values of rest and neighbouring demand in the last column of Table 6 is well below unity; this finding is also statistically validated by the chi-squared test in the penultimate column of Table 6).

Secondly, in the cases of HR, KN and KR, where external demand was found to be more important, this demand does not originate from rich neighbouring states as hypothesized but from the rest of India (this finding is statistically significant in the cases of $\mathrm{KN}$ and $\mathrm{KR}$ and also statistically validated for KR by the chi-squared test). Moreover, while external demand was a statistically significant determinant of services demand for $\mathrm{HR}, \mathrm{KN}, \mathrm{KR}$ and $\mathrm{OR}$, we find one of its components - demand from the rest of India - to be statistically significant for GJ as well.

Thirdly, demand from the neighbouring states seems more important than that from the rest of India for four states - AP, BH, TN and WB - and of these, neither BH nor WB has a rich neighbour. Statistically, this finding is validated by the chi-squared test for AP, BH and WB. In fact, the null of the ratio of rest and neighbouring demand equalling unity is conclusively rejected by nine of the fourteen states; in three of these, the ratio falls short (AP, BH and WB) while in the remaining six, it exceeds unity (KR, MH, MP, PJ, RJ and UP).

Thus, on the whole, despite the importance of internal demand for the large, servicesintensive states, external demand seems to be a more important determinant of services value added in a larger number of states. Moreover, our results do not seem to suggest either any "neighbourhood" or any "rich neighbour" effect on services demand; instead, wherever relevant, they rather point to the demand for services emanating from all over the country and the relative ease with which such services may in fact be crossing borders within India, thereby promoting convergence across states. 


\section{Conclusion}

The analysis in this paper confirms that India's states mirror the remarkable performance of the country's services sector at the national level. Critics of the services growth process, however, claim that this growth is not sustainable. Our results, however, suggest that the demand for services is spread throughout the country and that per capita services are converging across states and time, which makes this growth both progressive and politically sustainable. The services performance of Bihar is a case in point.

At the moment, convergence in services is not resulting in convergence in income due to the offsetting impact of divergence in industry and the concentration of the labour force in agriculture. However, with services growth adding further to services share in GDP and employing a greater share of the country's labour force, this growth is bound to have positive implications for income distribution. Moreover, services growth is not restricted to sectors like financial and business services where concentration effects are more pronounced, but is equally visible in construction, distribution, transport and tourism, where the benefits from the growth process are more widely distributed. Additionally, the human capital skill requirements are less intense in these sectors and the growth process would therefore involve a greater share of the labour force overtime, drawing people away from agriculture.

Literature also suggests that exports have contributed almost $25 \%$ to the growth of services value added (Eichengreen \& Gupta, 2010) overtime; in fact, the share of services exports in GDP has risen from 3\% in 1990 to $15 \%$ in 2006 . These results are also supported by the empirical analysis in this paper which suggests that even at the state level, external demand is an important determinant of services value added. All this coupled with India's current small share in global trade and its increasingly important role as a global services exporter also point to the potential for more services-export led growth going ahead. Significantly, in light of our results on convergence, such growth could also be more equalizing, which bodes well for the country's future, even from a political economy perspective. 


\section{Bibliography}

Aiyar, S. (2001) 'Growth Theory and Convergence across Indian States,' in India at the Crossroads: Sustaining Growth and Reducing Poverty, ed. by Tim Callen, Patricia Reynolds, and Christopher Towe (Washington: International Monetary Fund), pp. 143-69.

Amin, Mohammad \& Aaditya Mattoo (2008). 'Human Capital and the Changing Structure of the Indian Economy,' World Bank Policy Research Working Paper 4576, March.

Arunachalam R. and N. K. Kumar (2002). 'Inter-Temporal Comparison of Inter-industrial Linkages in the Indian Economy (1968-69 to 1983-83),' Reserve Bank of India Occasional Papers, 15 (1), March 1-30.

Bai, J. (2010). 'Likelihood approach to small $\mathrm{T}$ dynamic panel models with interactive effects.' Mimeo.

Bai J. \& Ng S. (2004). 'A panic attack on unit roots and cointegration,' Econometrica 72, $1127-1177$.

Bajpai, N. \& J. Sachs (1996). 'Trends in Inter-State Inequalities of Income in India,' Harvard Institute for International Development, Development Discussion Paper No. 528.

Baltagi, Badi H. (2003). Econometric Analysis of Panel Data, John Wiley \& Sons Ltd.

Bandyopadhyay, S. (2003) 'Convergence Club Empirics: Some Dynamics and Explanations of Unequal Growth across Indian States,' STICERD-Distribution Analysis Research Program Papers 69.

Banga, Rashmi (2005). 'Critical issues in India's Service-led Growth,' ICRIER Working Paper No. 171, October.

Barro R. \& Sala-i-Martin X. (1992). 'Convergence,' Journal of Political Economy 100 (2), 223-251.

Barro R. \& Sala-i-Martin X. (1995). Economic Growth. Mc Graw Hill, New-York.

Bernard, A. \& C. Jones (1996). 'Productivity across industries and countries: Times series theory and evidence,' The Review of Economics and Statistics 135-146.

Bhattacharya B. B. \& A. Mitra (1990). 'Industry-Agriculture Growth Rates: Widening Disparities: An Explanation,' Economic \& Political Weekly of India, August 26.

Breitung, J. \& S. Das (2005). 'Panel unit root tests under cross sectional dependence,' Statistica Neerlandica 52, 1-20.

Cashin, P. and R. Sahay (1996). 'Internal Migration, Center-State Grants, and Economic Growth in the States of India,' IMF Staff Papers, Vol. 43, No. 1. 
Chakravarty, Deepita (2005). 'Growing Services in India - An Inter-Sectoral Analysis Based on State-Level Data,' Centre for Economic \& Social Studies, Working Paper No. 64, October.

Chaudhury, Mahindar D (1974). 'Behaviour of Spatial Income Inequality in a developing Economy: India 1950-76, ' Paper presented at the Ninth Conference of the Indian Association for Research in National Income and Wealth.

Chudik, A., M.H. Pesaran \& E. Tosetti (2010). 'Weak and Strong Cross Section Dependence and Estimation of Large Panels, ECB Working Paper No. 1100.

Dasgupta, D, Pradip Maiti, Robin Mukherjee, Subrata Sarkar, and Subhendu Chakrabarti (2000). 'Growth and Interstate Disparities in India,' Economic and Political Weekly, Vol. XXXV, No. 27, July 1.

Dholakia, R (1994). 'Spatial Dimension of Acceleration of Economic Growth in India,' Economic and Political Weekly, Vol. XXIX, No. 35, August 21.

Eberhardt, M \& S. Bond (2009). 'Cross-sectional dependence in non-stationary panel models: A novel estimator,' MPRA Paper No. 17870.

Eichengreen, Barry \& Poonam Gupta (2010). 'The Service Sector as India's Road to Economic Growth?,' ICRIER Working Paper No. 249.

Evans, P. \& G. Karras (1996). 'Convergence revisited,' Journal of Monetary Economics 37, 249-265.

Evans, P. (1998) 'Income Dynamics in Regions and Countries,' Department of Economics Working Paper, Ohio State University.

Friedman, M. (1992). 'Do old fallacies ever die?,' Journal of Economic Literature 30, 2129 2132.

Ghosh, B., S. Marjit \& C. Neogi (1998). 'Economic growth and regional divergence in India: 1960 to 1995,' Economic and Political Weekly, June 27-3, 1623-1630.

Gordon, Jim \& Poonam Gupta (2003). 'Understanding India's Services Revolution,' IMF Working Paper.

Gunji, H. \& Y. Nikaido (2004). 'Convergence across Indian states: A revaluation.'

Gupta S. (1973). 'The Role of the Public Sector in Reducing Regional Income Disparity in India,' Journal of Development Studies, Vol. 9, No. 2, pp. 243-60.

Hansda, Sanjay Kumar (2002a). 'Services Sector in the Indian Economy: A Status Report,' RBI Staff Studies, Department of Economic Analysis and Policy, RBI.

Hansda, Sanjay Kumar (2002b). 'Sustainability of Services and Services-Led Growth: An Input Output Exploration of the Indian Economy,' RBI Papers. 
Im K., Pesaran H. and Y. Shin (2003). 'Testing for Unit Roots in Heterogeneous Panels,' Journal of Econometrics, 115, 53-74.

Johansen, S. (1988). 'Statistical Analysis of Cointegrating Vectors,' Journal of Economic Dynamics and Control, 12: 231-54.

Johansen, S. (1991). 'Estimation and Hypothesis Testing of Cointegration Vectors in Gaussian Vector Autoregressive Models,' Econometrica, 59: 1551-80.

Johansen, S. and K. Juselius (1990). 'Maximum Likelihood Estimation and Inference on Cointegration with Applications to the Demand for Money,' Oxford Bulletin of Economics and Statistics, 52: 169-210.

Johansen, S. and K. Juselius (1992), 'Testing Structural Hypothesis in a Multivariate Cointegration Analysis of the PPP and the UIP for UK,' Journal of Econometrics, 53: 21144.

Johansen, S. and K. Juselius (1994), 'Identification of the Long-Run and the Short-Run Structure: An Application to the ISLM Model,' Journal of Econometrics, 63: 7-36.

Kalra, S. \& P. Sodsriwiboon (2010). 'Growth Convergence and Spillovers among Indian States: What matters? What does not?,' IMF Working Paper No. 10/96.

Kapetanios, G., M. H. Pesaran \& T. Yagamata (2010). 'Panels with nonstationary multifactor error structures,' CESifo Working Paper No. 1788, August 2006, revised April 2010.

Kravis, Irving B., Alan W. Heston \& Robert Summers (1983). 'The Share of Services in Economic Growth,' in Global Econometrics, Chapters in Honor of Lawrence R. Klein, edited by F. Gerard Adams and Bert G. Hickman (Cambridge: The MIT Press, 1983), 188-218.

Kochhar, K., U. Kumar, R. Rajan, A. Subramanian \& I. Tokatlidis (2006). 'India's Pattern of Development: What Happened, What Follows,' IMF Working Paper No. 06/22.

Kurian, N.J. (2000). 'Widening Regional Disparities in India - Some Indicators,' Economic and Political Weekly, Vol. XXXV, No. 7, February 12-18.

Levin, A., Lin, F. and C. Chu (2002). 'Unit root tests in panel data: asymptotic and finitesample properties,' Journal of Econometrics, 108, 1-24.

Maddala, G.S. \& Wu, S. (1999). 'A Comparative Study of Unit Root Tests with Panel Data and a New Simple Test,' Oxford Bulletin of Economics and Statistics, 61, 631-652.

Majumdar, Grace and J L Kapoor (1980). 'Behavior of inter-state income inequalities in India,' Paper presented at the Twelfth Conference of the Indian Association for Research on National Income and Wealth.

Marjit, S. \& S. Mitra (1996). 'Convergence in regional growth rates: Indian research agenda,' Economic and Political Weekly XXXI (33), 2239-2242 August 17. 
Marjit Sugata, Saibal Kar and Dibyendu Maiti (2007). 'Regional Trade Openness Index and Income Disparity: A New Methodology and the Indian Experiment,' Economic \& Political Weekly, March 3.

Misra, B.S. (2007). Regional Growth Dynamics in India in the Post-Economic Reform Period, Palgrave Macmillan, 2007.

Mitra, A. (1988). 'Disproportionality and the Services Sector: A Note,' Social Scientist, April 3-8.

Moon, H.R. \& B. Perron (2004). 'Efficient estimation of the SUR cointegration regression model testing for purchasing power parity.'

Nagaraj, R., A. Varoudakis \& M.A.Veganzones (1997). 'Long-run growth trends and convergence across Indian states,' Mimeograph, IGIDR, Mumbai.

Nair, K R G (1971). 'A Note on Inter-State Income Differentials in India 1950-51 to 196061,' Journal of Development Studies, Vol. 7, No 1, pp. 441-47.

O'Connell, PG.J. (1998). 'The Overvaluation of Purchasing Power Parity,' Journal of International Economics, 44, 1-19.

Pesaran, M.H. (2003). 'Estimation and Inference in Large Heterogenous Panels with Cross Section Dependence,' CESifo Working Paper Series No. 869.

Pesaran, M.H. (2004). 'General Diagnostic Tests for Cross Section Dependence in Panels,' Cambridge Working Papers in Economics, No. 435, University of Cambridge, and CESifo Working Paper Series No. 1229.

Pesaran, M.H. (2005). 'A Simple Panel Unit Root Test in the Presence of Cross Section Dependence,' Cambridge University and USC.

Pesaran, M. H. (2006). 'Estimation and inference in large heterogeneous panels with a multifactor error structure,' Econometrica, 74(4), 967-1012.

Pesaran, M. H., Y. Shin \& R. J. Smith, (1997). 'Structural Analysis of Vector Error Correction Models with Exogenous I(1) Variables,' Cambridge Working Papers in Economics 9706, Faculty of Economics (formerly DAE), University of Cambridge.

Pesaran, M. H., Y. Shin \& R. J. Smith, (1999). 'Pooled mean group estimation of dynamic heterogeneous panels,' Journal of the American Statistical Association 94: 621-634.

Pesaran, M. H. \& E. Tosetti (2010). 'Large panels with common factors and spatial correlations,' CESifo Working Paper No. 2103, September 2007, revised January 2010.

Quah, D. (1993). 'Galton's fallacy and tests of the convergence hypothesis,' Scandinavian Journal of Economics 95, 427-443.

Quah, D. (1994). 'Exploiting cross-section variations for unit root inference in dynamic data,' Economics Letters 44, 9-19. 
Rao, M.G., R.T. Shand \& K.P.Kalirajan (1999). 'Convergence of Incomes Across Indian States - A Divergent View,' Economic and Political Weekly, Vol. XXXIV, No. 13, March 27.

Robertson, D., V. Sarafidis, and J. Symons (2010). 'IV Estimation of Panels with Factor Residuals.' Mimeo.

Sachs, Jeffrey D., Nirupam Bajpai \& Ananthi Ramiah (2002). 'Understanding Regional Economic Growth in India,' CID Working Paper No. 88, March.

Salgado, Ranil (2003). 'India's Global Integration and the Role of the IT Sector,' India: Selected Issues, IMF.

Sarafidis, Vasilis (2007). 'Consistent estimation of dynamic panel data models with crosssectional dependence.'

Sarafidis, V. \& D. Robertson (2009). 'On the Impact of Error Cross-sectional Dependence in Short Dynamic Panel Estimation,’ The Econometrics Journal, 12(1),62-81.

Sarafidis, V. \& T. Wansbeek (2010). 'Cross-sectional Dependence in Panel Data Analysis.'

Sarkar, P.C. (1994). 'Regional Imbalances in Indian Economy over Plan Periods,' Economic and Political Weekly, Vol. XXIX, No. 2, March 12.

Stock, J. \& M. Watson (1993). 'A Simple Estimator of Cointegrating Vectors in Higher Order Integrated Systems.” Econometrica 61, no. 4: 783-820.

Sul, D. (2009). 'Panel Unit Root Tests under Cross Section Dependence with Recursive Mean Adjustment.'

Temple, J. (1999). 'The new growth evidence,' Journal of Economic Literature 37, 112-156.

Verma, Rubina (2006). 'India's Service Sector Growth: A “New” Revolution,' DEGIT Conference Paper.

http://www.degit.ifw-kiel.de/papers/degit_11/C011_020.pdf

Wu, Yanrui (2004). 'Service Sector Growth in China and India: A Comparison,' School of Economics and Commerce, University of Western Australia, Economics Discussion/Working Paper 07-04. 
Figure 1: Scatter plot of services share in GSDP against real PCY levels for major states

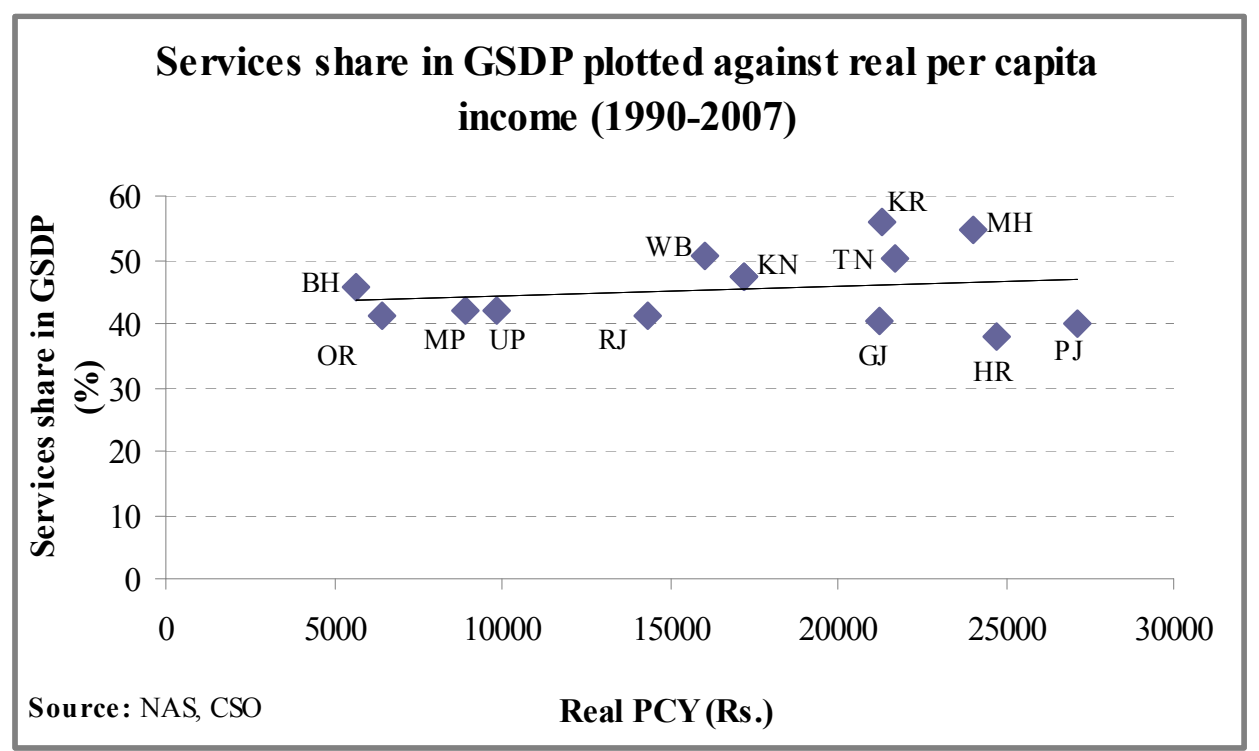


Table 1: A snapshot of India's states

\begin{tabular}{|c|c|c|c|c|c|c|c|c|c|c|c|c|c|c|c|c|c|}
\hline \multirow[b]{2}{*}{ State } & \multicolumn{3}{|c|}{ Population (mn) } & \multicolumn{3}{|c|}{$\begin{array}{l}\text { Real per capita income (Indian } \\
\text { Rupees) }\end{array}$} & \multicolumn{3}{|c|}{$\begin{array}{c}\text { Services share in real GSDP } \\
(\%)\end{array}$} & \multicolumn{3}{|c|}{$\begin{array}{l}\text { Growth rate of real services } \\
\text { value-added (\%) }\end{array}$} & \multicolumn{3}{|c|}{ Services share in employment (\%) } & \multicolumn{2}{|c|}{$\begin{array}{c}\text { Growth rate of } \\
\text { services employment } \\
(\%)\end{array}$} \\
\hline & $1980-90$ & $1990-2000$ & 2000-07 & $1980-90$ & $1990-2000$ & 2000-07 & $1980-90$ & $1990-2000$ & 2000-07 & $1980-90$ & $1990-2000$ & 2000-07 & Avg. 1983, 88 & 1994 & Avg. 2000, 04 & $1994 / 80 \mathrm{~s}$ & 2000s/94 \\
\hline Uttar Pradesh*(UP) & 122.1 & 150.2 & 173.3 & 5006 & 8916 & 11291 & 35.5 & 38.6 & 44.7 & 5.6 & 4.8 & 6.0 & 21.8 & 24.8 & 29.0 & 35.2 & 33.3 \\
\hline Maharashtra* (MH) & 68.9 & 86.2 & 100.2 & 13512 & 21510 & 28163 & 43.9 & 50.4 & 58.7 & 5.9 & 7.5 & 8.5 & 24.9 & 29.6 & 35.3 & 43.1 & 33.3 \\
\hline Bihar* (BH) & 76.5 & 94.6 & 87.1 & 4168 & 4534 & 7264 & 30.7 & 36.1 & 54.8 & 5.8 & 4.7 & 6.2 & 17.2 & 19.0 & 21.1 & 32.9 & 30.2 \\
\hline West Bengal* (WB) & 59.7 & 73.4 & 82.4 & 9791 & 13768 & 19790 & 44.6 & 47.5 & 53.5 & 4.5 & 7.4 & 7.6 & 29.7 & 33.1 & 34.9 & 37.4 & 20.3 \\
\hline Andhra Pradesh* (AP) & 58.6 & 71.0 & 78.6 & 9865 & 14398 & 21157 & 39.0 & 44.3 & 49.6 & 6.6 & 6.4 & 8.5 & 22.3 & 24.1 & 30.5 & 39.9 & 28.2 \\
\hline Tamil Nadu* (TN) & 51.6 & 58.6 & 63.8 & 13144 & 19422 & 24937 & 35.7 & 43.4 & 56.8 & 6.3 & 8.5 & 7.1 & 28.5 & 30.6 & 34.4 & 26.2 & 19.0 \\
\hline Madhya Pradesh* (MP) & 57.5 & 88.5 & 62.9 & 5864 & 6368 & 13208 & 32.7 & 35.5 & 49.6 & 5.0 & 6.2 & 5.0 & 15.2 & 17.4 & 22.3 & 37.6 & 38.7 \\
\hline Rajasthan* (RJ) & 38.3 & 48.8 & 59.6 & 8711 & 13031 & 16152 & 36.0 & 39.7 & 42.9 & 8.1 & 8.0 & 7.1 & 24.2 & 28.5 & 31.2 & 37.2 & 21.4 \\
\hline Karnataka* (KN) & 40.5 & 48.4 & 54.3 & 9619 & 14678 & 21477 & 37.1 & 43.4 & 51.1 & 6.3 & 8.9 & 8.0 & 22.2 & 23.9 & 27.7 & 34.3 & 30.0 \\
\hline Gujarat* (GJ) & 37.2 & 44.7 & 52.5 & 12183 & 18723 & 25337 & 30.4 & 32.0 & 37.6 & 6.9 & 8.7 & 9.5 & 26.9 & 26.7 & 30.2 & 17.7 & 37.5 \\
\hline Orissa* (OR) & 28.4 & 33.8 & 37.6 & 4944 & 5819 & 7424 & 29.9 & 37.4 & 45.1 & 6.3 & 5.5 & 7.9 & 20.2 & 19.4 & 24.0 & 12.6 & 27.1 \\
\hline Kerala* (KR) & 27.0 & 30.3 & 32.7 & 11856 & 17670 & 26547 & 47.8 & 51.5 & 59.4 & 3.5 & 7.1 & 9.2 & 36.0 & 41.9 & 50.5 & 35.7 & 28.8 \\
\hline Jharkhand (JH) & & & 28.2 & & & 14281 & & & 38.3 & & & 6.6 & & & 29.1 & & \\
\hline Assam (AS) & & 24.9 & 27.4 & & 1559 & 1807 & 36.3 & 42.1 & 48.1 & 4.5 & 3.8 & 6.4 & 25.9 & 26.1 & 31.7 & 25.8 & 56.3 \\
\hline Punjab* (PJ) & 18.1 & 21.9 & 25.6 & 18740 & 24760 & 30486 & 37.6 & 36.9 & 42.5 & 4.0 & 5.7 & 6.0 & 32.7 & 40.2 & 44.8 & 45.6 & 35.2 \\
\hline Haryana* (HY) & 14.3 & 18.2 & 22.0 & 16137 & 21981 & 29325 & 29.2 & 33.3 & 41.9 & 5.8 & 6.4 & 10.7 & 29.1 & 44.3 & 41.5 & 76.6 & 21.2 \\
\hline Chattisgarh (CH) & & & 21.6 & & & 6090 & & & 39.2 & & & 7.1 & & & 20.5 & & \\
\hline Jammu \& Kashmir (JK) & & 9.1 & 10.6 & & 14854 & 16570 & 36.9 & 42.5 & 46.4 & & & 4.4 & 34.7 & 46.7 & 40.8 & 69.9 & 12.7 \\
\hline Uttaranchal (UT) & & & 8.8 & & & 19657 & & & 49.8 & & & 9.9 & & & 33.9 & & \\
\hline Himachal Pradesh (HP) & & 5.7 & 6.4 & & 20434 & 28531 & 34.8 & 36.7 & 38.0 & 5.3 & 7.5 & 8.0 & 18.2 & 27.0 & 33.3 & 81.2 & 28.9 \\
\hline Tripura (TR) & & 3.1 & 3.2 & & 7077 & 10949 & & 54.5 & 52.8 & & 10.4 & 11.4 & 54.8 & 52.4 & 57.2 & 29.3 & 19.8 \\
\hline Manipur (MA) & & 2.1 & 2.4 & & 12761 & 16452 & 42.3 & 48.6 & 43.1 & & 6.6 & 13.4 & 26.9 & 35.7 & 30.6 & 73.8 & 4.5 \\
\hline Meghalaya (ME) & & 2.1 & 2.4 & & 14318 & 19071 & 46.7 & 53.0 & 51.3 & & & 6.5 & 20.5 & 20.4 & 21.7 & 67.5 & -3.6 \\
\hline Nagaland (NA) & & 1.6 & 2.2 & & 16266 & 18407 & & 59.4 & 53.9 & & 3.8 & 7.8 & 85.6 & 46.0 & 40.6 & -49.8 & 67.4 \\
\hline Goa (GO) & & 1.3 & 1.5 & & 38950 & 49331 & 48.5 & 50.4 & 47.1 & 6.6 & 7.8 & 9.2 & 49.3 & 60.4 & 64.6 & 66.9 & 6.9 \\
\hline Arunachal Pradesh (AR) & & 1.0 & 1.1 & & 9750 & 11009 & 32.6 & 38.2 & 44.0 & 8.0 & 7.7 & 10.4 & 60.9 & 19.6 & 22.9 & -45.5 & -7.1 \\
\hline Mizoram (MZ) & & & 0.9 & & 18083 & 20071 & & 61.4 & 64.4 & & & 7.3 & 21.6 & 23.8 & 31.8 & 45.8 & 60.0 \\
\hline Sikkim (SI) & & 0.5 & 0.6 & & 10142 & 13033 & & 48.8 & 52.1 & & 10.4 & 8.4 & 32.0 & 40.9 & 43.6 & 71.8 & 25.4 \\
\hline ALL INDIA & 748 & 919 & 1072 & 11785 & 16310 & 22243 & 36.9 & 41.9 & 48.3 & 7.1 & 7.4 & 8.4 & 24.4 & 27.3 & 31.1 & 35.8 & 28.7 \\
\hline
\end{tabular}

Source: National Account Statistics, CSO; National Sample Survey Organization; various years. (Own calculations)

Note: $(1) *$ indicates the 14 major states (2) The table is sorted by descending order of population by state over 2000-07 (3) Figures exceeding the all-India numbers are italicised (4) For the new states of CH, JH and UT, the employment data is only for the year 2004. 
Table 2: Sectoral breakdown of services contribution to GSDP and employment by state (2000-07)

\begin{tabular}{|c|c|c|c|c|c|c|c|c|c|c|c|c|c|c|c|c|c|c|c|c|c|c|c|c|c|c|}
\hline \multirow[b]{2}{*}{ State } & & & & & & are of $\mathbf{G S}$ & & & & & & & & & & $v$ th rates $(\%) \sim$ & & & & & \multicolumn{6}{|c|}{$\sim$ Svs emp (\% share of total emp) } \\
\hline & Constrn & Uts & Rlys & Other trans & Comm & Trade, H\&R & FS & RE \& bus. & PubAd & Others & Constrn & Uts & Rlys & Other trans & Comm & Trade, H\&R & FS & RE \& bus. & PubAd & Others & Constrn & Uts & TSC & Trade, H\&R & FS & CSP \\
\hline UP* & 5.5 & 3.9 & 1.8 & 4.3 & 2.2 & 12.3 & 3.8 & 6.9 & 5.4 & 8.0 & 14.0 & 20.6 & 15.0 & 22.1 & 38.1 & 12.4 & 14.3 & 16.5 & 16.0 & 19.7 & 5.8 & 0.2 & 4.0 & 11.0 & 1.1 & 8.6 \\
\hline $\mathrm{MH}^{*}$ & 5.2 & 2.6 & 0.7 & 5.2 & 3.4 & 15.6 & 11.6 & 10.8 & 4.2 & 7.4 & 30.5 & -0.1 & 4.8 & 6.6 & 11.8 & 5.0 & 10.6 & 3.7 & 2.6 & 1.4 & 4.9 & 0.4 & 5.4 & 11.2 & 2.8 & 10.5 \\
\hline $\mathrm{BH}^{*}$ & 4.7 & 1.1 & 3.1 & 2.5 & 1.7 & 18.4 & 3.9 & 4.0 & 6.9 & 14.1 & 8.9 & -1.2 & 14.4 & 12.4 & 12.1 & 8.4 & 7.5 & 4.4 & 8.9 & 3.6 & 3.1 & 0.2 & 2.6 & 8.8 & 0.7 & 6.2 \\
\hline WB* & 5.7 & 1.8 & 1.4 & 4.8 & 2.0 & 15.2 & 6.2 & 9.0 & 5.2 & 9.7 & 13.1 & 8.7 & 5.6 & 6.4 & 15.6 & 6.4 & 3.3 & 11.7 & 3.8 & 5.4 & 4.2 & 0.3 & 5.8 & 13.2 & 1.8 & 10.0 \\
\hline $\mathrm{AP}^{*}$ & 6.3 & 2.5 & 1.5 & 4.6 & 2.8 & 13.4 & 4.7 & 8.4 & 4.7 & 9.7 & 8.7 & 3.9 & 6.2 & 8.5 & 23.6 & 7.4 & 8.6 & 8.4 & 4.8 & 6.7 & 4.9 & 0.2 & 4.4 & 9.9 & 1.4 & 9.7 \\
\hline $\mathrm{TN}^{*}$ & 7.3 & 1.8 & 1.1 & 5.9 & 3.4 & 16.3 & 7.6 & 7.6 & 5.1 & 9.8 & 31.5 & 40.7 & 4.4 & 5.5 & 17.8 & 2.3 & 12.3 & 12.9 & 9.1 & 6.5 & 5.9 & 0.3 & 4.9 & 11.6 & 2.5 & 9.5 \\
\hline MP* & 6.8 & 3.2 & 2.5 & 3.0 & 1.9 & 15.4 & 4.2 & 7.7 & 4.7 & 10.2 & 7.1 & 10.7 & 5.0 & 6.3 & 16.7 & 6.0 & 9.2 & 2.8 & 4.9 & 3.1 & 3.9 & 0.2 & 2.3 & 7.9 & 0.8 & 7.7 \\
\hline $\mathrm{RJ}{ }^{*}$ & 10.6 & 3.8 & 1.4 & 2.9 & 2.3 & 13.2 & 3.7 & 6.8 & 4.1 & 8.2 & 12.0 & 2.1 & 8.9 & 6.5 & 19.8 & 3.4 & 8.7 & 4.4 & 3.0 & 2.6 & 10.6 & 0.5 & 3.6 & 8.0 & 1.3 & 8.0 \\
\hline KN* & 7.3 & 2.6 & 0.6 & 4.1 & 2.9 & 12.8 & 6.3 & 12.2 & 4.4 & 8.0 & 6.2 & 5.3 & 11.5 & 7.1 & 24.2 & 8.6 & 8.6 & 9.6 & 3.1 & 3.5 & 4.0 & 0.2 & 3.6 & 10.1 & 1.9 & 7.8 \\
\hline GJ* & 5.6 & 2.8 & 0.8 & 4.5 & 2.7 & 14.6 & 5.8 & 5.5 & 3.4 & 5.9 & 10.9 & 7.2 & 7.2 & 8.1 & 22.0 & 11.9 & 5.1 & 2.3 & -1.0 & 3.7 & 4.7 & 0.3 & 4.5 & 10.8 & 1.3 & 8.2 \\
\hline $\mathrm{OR}^{*}$ & 4.4 & 2.8 & 3.1 & 5.2 & 2.9 & 10.3 & 5.1 & 5.3 & 5.4 & 7.7 & -1.7 & 9.7 & 8.2 & 11.3 & 27.4 & 7.2 & 12.9 & 3.7 & 1.7 & 3.5 & 5.8 & 0.3 & 2.8 & 8.4 & 1.0 & 7.3 \\
\hline $\mathrm{KR}^{*}$ & 10.7 & 2.0 & 0.5 & 7.2 & 3.7 & 20.1 & 5.6 & 9.1 & 4.9 & 8.3 & 10.3 & 8.0 & 8.4 & 10.3 & 24.2 & 4.1 & 10.5 & 9.5 & 9.1 & 3.9 & 11.6 & 0.4 & 8.4 & 15.8 & 3.2 & 12.8 \\
\hline $\mathrm{JH}$ & 6.2 & 1.9 & 3.1 & 2.7 & 2.0 & 9.8 & 2.2 & 4.5 & 5.3 & 8.3 & 4.3 & 6.0 & 6.1 & 3.3 & 14.6 & 7.3 & 7.4 & 7.0 & 18.5 & 4.0 & 10.8 & 0.3 & 3.6 & 9.0 & 1.3 & 6.0 \\
\hline AS & 5.5 & 1.5 & 1.8 & 3.2 & 1.6 & 13.1 & 3.4 & 3.4 & 6.1 & 15.5 & 10.3 & 16.8 & 8.2 & 6.3 & 7.3 & 7.6 & 6.8 & 7.6 & 3.3 & 4.3 & 2.8 & 0.3 & 3.8 & 11.3 & 0.7 & 15.9 \\
\hline PJ* & 5.6 & 3.2 & & & & 12.9 & 4.9 & 4.5 & 4.8 & 8.6 & 10.7 & 2.7 & & & & 5.3 & 6.7 & 3.0 & 3.1 & 3.2 & 9.1 & 1.3 & 6.5 & 14.4 & 1.9 & 13.0 \\
\hline $\mathrm{HR}^{*}$ & 9.2 & 1.5 & 1.2 & 5.3 & 1.7 & 16.5 & 3.6 & 3.8 & 3.0 & 6.8 & 12.1 & 7.2 & 9.3 & 13.3 & 25.4 & 12.9 & 6.5 & 5.5 & 5.2 & 6.1 & 8.9 & 0.9 & 5.6 & 14.0 & 1.9 & 11.6 \\
\hline $\mathrm{CH}$ & 4.2 & 3.9 & 2.0 & 2.8 & 1.5 & 11.0 & 2.6 & 5.8 & 4.2 & 9.1 & 13.3 & -3.2 & 5.9 & 11.6 & 14.7 & 11.4 & 6.4 & 6.4 & 8.2 & 25.5 & 4.8 & 0.1 & 8.8 & & 10.0 & \\
\hline JK & 10.6 & 7.4 & & 4.2 & & 7.3 & 4.2 & 6.7 & 13.9 & 10.1 & 8.5 & -0.4 & & 11.3 & & 3.6 & 7.7 & 2.8 & 0.0 & 7.6 & 11.2 & 1.2 & 4.5 & 9.8 & 0.7 & 15.4 \\
\hline UT & 10.6 & 3.2 & 1.6 & 4.6 & 1.9 & 16.1 & 3.4 & 5.5 & 5.8 & 10.8 & 18.9 & 24.1 & 5.9 & 12.1 & 17.5 & 8.0 & 7.6 & 4.2 & 8.7 & 8.9 & 8.2 & 0.5 & 3.8 & 11.4 & 1.3 & 11.8 \\
\hline HP & 19.0 & 6.2 & & 2.9 & & 9.2 & 4.3 & 4.6 & 6.2 & 9.9 & 7.0 & 13.5 & 6.5 & 10.7 & 1.6 & 7.5 & 13.0 & 3.0 & 4.1 & 4.7 & 12.7 & 2.0 & 3.7 & 5.0 & 0.9 & 10.1 \\
\hline TR & 19.1 & 2.3 & & 3.2 & 4.4 & 12.0 & 2.3 & 3.0 & 14.5 & 13.4 & 14.3 & 18.6 & 16.5 & 5.3 & 59.7 & 5.6 & 13.9 & 3.8 & 6.6 & 2.2 & 9.6 & 0.1 & 3.4 & 13.3 & 0.4 & 30.5 \\
\hline MA & 22.8 & 3.3 & & 1.7 & 1.0 & 7.7 & 1.8 & 3.0 & 14.7 & 12.1 & 1.6 & 2.0 & 3.6 & 5.2 & 1.0 & 13.2 & 11.7 & 12.1 & 8.3 & 13.9 & 3.0 & 0.0 & 2.7 & 8.6 & 0.5 & 16.5 \\
\hline $\mathrm{ME}$ & 9.9 & 3.7 & & 5.6 & 1.6 & 9.8 & 3.1 & 9.5 & 13.4 & 8.3 & 7.8 & 3.9 & & 9.1 & & 9.1 & 5.9 & 9.6 & 3.3 & 4.6 & 2.5 & 0.3 & 1.6 & 6.5 & 0.2 & 11.8 \\
\hline NA & 10.7 & 1.5 & 0.1 & 13.9 & 1.4 & 5.3 & 1.4 & 10.6 & 13.9 & 8.3 & 13.0 & 11.3 & 14.9 & 6.9 & 16.2 & 10.4 & 18.2 & 11.9 & 7.6 & 6.6 & 2.3 & 1.0 & 1.9 & 10.9 & 0.5 & 25.6 \\
\hline GO & 5.4 & 2.1 & 0.4 & 12.3 & 0.8 & 10.2 & 8.3 & 6.3 & 4.4 & 4.4 & 3.2 & 9.8 & 8.8 & 15.4 & 18.3 & -4.1 & 7.8 & 5.3 & -1.1 & 5.3 & 13.5 & 1.3 & 13.2 & 21.4 & 2.7 & 15.5 \\
\hline AR & 19.7 & 5.4 & & 2.9 & 2.2 & 5.7 & 2.5 & 2.8 & 16.1 & 11.5 & 24.2 & 44.7 & 158.7 & 4.6 & 9.6 & 6.3 & 6.9 & 4.0 & 7.2 & 5.5 & 4.7 & 0.7 & 0.4 & 4.4 & 0.5 & 12.3 \\
\hline $\mathrm{MZ}$ & 11.2 & 4.4 & & 1.6 & 0.7 & 7.9 & 3.0 & 15.8 & 21.2 & 13.9 & 9.5 & 6.5 & 17.1 & 12.7 & 15.0 & -0.2 & 14.8 & 9.2 & 11.2 & 3.3 & 3.4 & 0.0 & 1.4 & 8.5 & 0.6 & 18.1 \\
\hline SI & 17.4 & 5.7 & & 4.1 & & 5.1 & 3.1 & 6.6 & 18.0 & 15.1 & 5.3 & 1.2 & & 14.3 & & 6.4 & 6.9 & 8.9 & 4.3 & 5.8 & 5.8 & 1.9 & 3.4 & 10.0 & 0.6 & 19.7 \\
\hline Average & 6.7 & 2.7 & 1.5 & 4.6 & 2.2 & 14.4 & 5.9 & 7.7 & 4.9 & 8.8 & 11.3 & 10.0 & 15.0 & 9.4 & 18.9 & 6.9 & 9.3 & 6.9 & 5.9 & 6.3 & 6.5 & 0.5 & 4.3 & 10.6 & 1.6 & 12.6 \\
\hline
\end{tabular}

Source: National Account Statistics, CSO; National Sample Survey Organization; own calculation

Note: (1) The employment shares are averages of data in 2000 and 2004 except for CH, JH and UT where data is only for 2004 (2) * indicates the 14 major states (3) The table is sorted by descending order of population by state over 2000-07 (4) Figures exceeding the average numbers are italicised (5) Sectors read left to right as follows: Construction; Utilities; Railways; Other transport; Communications; Trade, Hotels \& Restaurants; Financial Services; Real estate \& business; and Public Administration. "TSC" stands for Transport, Storage \& Communications and "CSP" for Community, Social \& Personal Services. 


\section{Table 3: List of variables, description and data source}

\begin{tabular}{|c|c|c|}
\hline Variable & Description & Data Source \\
\hline PCSVS & State's per capita services value added & $\begin{array}{l}\text { NAS, CSO, various years } \\
\text { (author's calculations) }\end{array}$ \\
\hline TREND & $\begin{array}{l}\text { The time trend for productivity which is used as a proxy for } \\
\text { technological advancements measured by trade restrictiveness indices }\end{array}$ & \\
\hline Internaldd & State's per capita income & NAS, CSO, various years \\
\hline Externaldd & $\begin{array}{l}\text { The ratio of GDP for India minus GSDP for a state to the population } \\
\text { of India minus the population of that state }\end{array}$ & $\begin{array}{l}\text { NAS, CSO, various years } \\
\text { (author's calculations) }\end{array}$ \\
\hline LIB & Values from an openness index for Indian states over 1980-2003 & $\begin{array}{l}\text { Developed by Marjit Sugata, } \\
\text { Saibal Kar and Dibyendu Maiti } \\
(2007)^{30}\end{array}$ \\
\hline URB & The share of urban population in a state's total population & Census Reports, various years \\
\hline GATS & $\begin{array}{l}\text { A dummy variable that takes the value of } 1 \text { from } 1995 \text { onwards and } 0 \\
\text { before that }\end{array}$ & \\
\hline CREATION & $\begin{array}{l}\text { A dummy variable for Bihar, MP and UP that takes the value } 1 \text { in } \\
2000-01 \text { to control for the creation of the three new states }\end{array}$ & \\
\hline
\end{tabular}

\footnotetext{
${ }^{30}$ In the absence of trade data in India at the state level, the authors link the level of output of a specific state to all-India trade figures to get an approximate indicator of how much 'open' it is. If for a specific state most of the production is concentrated in items that contribute largely to export value at the all-India level, then it is reasonable to conclude that the particular state is attuned to exports. Similarly, if a state has high production value of import substitutes, then it must be relying less on imports and hence is not so open.
} 
Table 4: Results from estimation

DGLS, original data

DGLS, factor scores

DGLS, mean centered

\begin{tabular}{|c|c|c|c|c|c|c|c|c|c|c|c|c|c|c|c|c|c|c|c|c|c|}
\hline State & Intercept & Intdd & Extdd & Urb & Lib & Extdd=Intdd & Abs(extdd/intdd) & Intercept & Intdd & Extdd & Urb & Lib & Extdd=Intdd & Abs(extdd/intdd) & Intercept & Intdd & Extdd & Urb & Lib & Extdd=Intdd & Abs(extdd/intdd $)$ \\
\hline \multirow[t]{2}{*}{ AP } & -3.42 & 0.88 & 0.08 & 0.92 & -0.20 & N & 0.09 & -6.70 & 0.97 & 0.11 & 1.12 & -0.24 & N & 0.12 & 6.35 & 0.90 & 0.02 & 0.93 & -0.21 & $\mathbf{N}$ & 0.02 \\
\hline & -2.7 & 8.3 & 0.5 & 3.4 & -3.6 & 14.8 & & -8.7 & 8.8 & 3.6 & 4.6 & -4.1 & 6.6 & & 513.1 & 8.8 & 0.1 & 3.8 & -3.8 & 14.8 & \\
\hline \multirow[t]{2}{*}{ BH } & 2.43 & 1.94 & -0.64 & -0.64 & 0.21 & $\mathbf{N}$ & 0.33 & -3.70 & 1.93 & 0.25 & -0.75 & 0.23 & $\mathbf{N}$ & 0.13 & 5.13 & 1.92 & -0.68 & -0.68 & 0.22 & $\mathbf{N}$ & 0.36 \\
\hline & 3.5 & 8.3 & -5.1 & -4.3 & 4.9 & 55.2 & & 2.1 & 7.6 & -4.6 & -5.6 & 5.5 & 44.0 & & -64.9 & 8.3 & -5.3 & -4.9 & 5.2 & 55.2 & \\
\hline \multirow[t]{2}{*}{ GJ } & -5.46 & 0.39 & -0.23 & 3.13 & -0.33 & $\mathrm{Y}$ & 0.59 & $-10.2 \#$ & 0.38 & 0.45 & 3.94 & -0.30 & $\mathrm{Y}$ & 1.17 & $6.42 \#$ & 0.38 & -0.18 & 2.80 & -0.35 & $\mathrm{Y}$ & 0.47 \\
\hline & -1.1 & -3.9 & -1.0 & 2.0 & -1.3 & 0.6 & & -1.8 & -4.5 & -1.1 & 2.5 & -0.5 & 0.3 & & 1.9 & -4.3 & -0.6 & 1.6 & -1.3 & 0.6 & \\
\hline \multirow[t]{2}{*}{ HR } & -1.21 & 0.46 & 1.30 & -1.64 & 0.02 & $\mathbf{N}$ & 2.83 & -4.69 & 0.59 & $0.59 \#$ & $-0.84 \#$ & 0.00 & $\mathbf{N}$ & 1.00 & 6.72 & 0.51 & 1.21 & -1.59 & 0.00 & $\mathbf{N}$ & 2.37 \\
\hline & 2.5 & -2.3 & 2.4 & -2.3 & 2.9 & 7.0 & & 2.5 & -2.0 & 1.9 & -1.8 & 3.1 & 5.0 & & 4.3 & -2.1 & 2.4 & -2.3 & 2.9 & 7.0 & \\
\hline \multirow[t]{2}{*}{ KN } & -3.01 & $0.62 \#$ & 0.52 & 0.29 & 0.00 & $\mathbf{N}$ & 0.84 & -10.96 & 0.23 & 0.26 & 2.52 & -0.04 & $\mathbf{N}$ & 1.14 & 6.46 & 0.45 & 0.51 & 1.07 & 0.00 & $\mathbf{N}$ & 1.13 \\
\hline & 0.3 & -2.0 & 2.9 & -1.1 & 3.4 & 14.7 & & -3.9 & -5.5 & 3.9 & 3.0 & 3.3 & 24.2 & & 5.7 & -3.5 & 3.7 & 0.3 & 3.5 & 14.7 & \\
\hline \multirow[t]{2}{*}{ KR } & -0.36 & 0.15 & 1.00 & -0.41 & -0.11 & $\mathbf{N}$ & 6.57 & -3.49 & 0.35 & 0.29 & -0.19 & -0.13 & $\mathbf{N}$ & 0.81 & 6.72 & 0.25 & 0.85 & -0.33 & -0.15 & $\mathbf{N}$ & 3.34 \\
\hline & 4.0 & -5.3 & 5.8 & -5.1 & 1.3 & 26.0 & & 4.6 & -4.1 & 4.3 & -5.2 & 1.5 & 18.1 & & 26.1 & -4.8 & 5.2 & -5.1 & 0.9 & 26.0 & \\
\hline \multirow[t]{2}{*}{ MP } & 4.82 & 1.32 & 0.97 & -3.64 & -0.02 & $\mathrm{~N}$ & 0.73 & -2.36 & 1.31 & 0.27 & -2.48 & -0.04 & $\mathrm{Y}$ & 0.21 & 5.50 & 1.30 & 1.02 & -3.89 & -0.03 & $\mathbf{N}$ & 0.79 \\
\hline & 8.2 & 4.2 & 4.5 & -9.3 & 3.3 & 5.6 & & 5.7 & 3.3 & 3.6 & -8.7 & 3.4 & 0.9 & & -32.7 & 4.0 & 5.3 & -10.4 & 3.2 & 5.6 & \\
\hline \multirow[t]{2}{*}{ MH } & -9.44 & 0.53 & -0.94 & 5.22 & -0.08 & N\# & 1.80 & -15.85 & 0.54 & 0.34 & 7.09 & -0.08 & $\mathbf{N}$ & 0.63 & 6.89 & 0.58 & -0.99 & 4.94 & -0.08 & $\mathbf{N}$ & 1.70 \\
\hline & -2.9 & -2.3 & -4.3 & 3.9 & 1.5 & 6.2 & & -4.5 & -2.7 & -6.1 & 5.6 & 1.9 & 11.8 & & 13.4 & -2.1 & -4.4 & 3.8 & 1.6 & 6.2 & \\
\hline \multirow[t]{2}{*}{ OR } & -0.62 & 0.10 & 1.38 & -2.01 & 0.10 & $\mathbf{N}$ & 13.20 & -4.12 & 0.09 & 0.46 & -0.76 & 0.09 & $\mathbf{N}$ & 5.25 & 5.33 & 0.12 & 1.17 & -1.51 & 0.09 & $\mathbf{N}$ & 9.45 \\
\hline & 3.2 & -4.6 & 3.9 & -3.5 & 4.5 & 15.5 & & 3.1 & -5.1 & 3.1 & -2.1 & 5.0 & 16.4 & & -31.7 & -4.6 & 3.3 & -2.8 & 4.5 & 15.5 & \\
\hline \multirow[t]{2}{*}{ PJ } & -0.10 & 0.87 & -0.18 & 0.39 & 0.07 & $\mathrm{Y}$ & 0.21 & -3.88 & 1.06 & 0.34 & 0.83 & 0.06 & $\mathrm{Y}$ & 0.32 & 6.96 & 0.60 & 0.09 & 0.02 & 0.07 & $\mathrm{Y}$ & 0.15 \\
\hline & 2.9 & 0.0 & -1.0 & -0.8 & 4.8 & 0.7 & & 2.8 & 0.4 & -2.0 & -0.5 & 4.9 & 1.8 & & 19.8 & -1.3 & 0.3 & -1.5 & 4.8 & 0.7 & \\
\hline \multirow[t]{2}{*}{ RJ } & -17.93 & 0.31 & -0.45 & 7.92 & 0.16 & $\mathrm{Y}$ & 1.46 & -22.25 & 0.24 & 0.36 & 8.40 & 0.15 & $\mathrm{Y}$ & 1.50 & 6.08 & 0.30 & $-0.44 \#$ & 7.47 & 0.15 & $\mathrm{Y}$ & 1.45 \\
\hline & -4.5 & -3.4 & -2.1 & 4.9 & 4.9 & 0.1 & & -4.9 & -4.2 & -1.5 & 5.3 & 5.2 & 0.8 & & -7.7 & -3.7 & -1.8 & 4.3 & 4.8 & 0.1 & \\
\hline \multirow[t]{2}{*}{ TN } & $-1.42 \#$ & 0.86 & 0.48 & -0.56 & 0.00 & $\mathrm{Y}$ & 0.56 & -4.10 & 0.99 & 0.41 & -0.65 & 0.01 & $\mathrm{Y}$ & 0.41 & 6.63 & 0.97 & 0.25 & -0.51 & -0.01 & $\mathrm{Y}$ & 0.26 \\
\hline & 1.9 & -0.1 & 1.3 & -4.6 & 3.4 & 0.1 & & 2.8 & 0.1 & 1.3 & -5.7 & 4.0 & 0.6 & & 14.9 & 0.4 & 0.8 & -4.8 & 3.2 & 0.1 & \\
\hline \multirow[t]{2}{*}{ UP } & (omitted) & 0.70 & 0.14 & 1.96 & 0.39 & $\mathrm{Y}$ & 0.20 & -11.54 & 0.80 & 0.24 & 3.12 & 0.32 & $\mathrm{Y}$ & 0.30 & 5.41 & $0.71 \#$ & 0.04 & 2.19 & 0.45 & $\mathrm{Y}$ & 0.05 \\
\hline & & -1.6 & 0.4 & 2.2 & 6.4 & 0.9 & & -3.8 & -1.5 & -1.3 & 4.0 & 5.8 & 0.0 & & -30.5 & -1.7 & 0.1 & 2.5 & 7.0 & 0.9 & \\
\hline \multirow[t]{2}{*}{ WB } & 31.1 & 0.99 & 0.67 & -11.09 & -0.03 & $\mathrm{Y}$ & 0.68 & 15.97 & 1.17 & 0.29 & -6.82 & 0.00 & $\mathrm{Y}$ & 0.25 & 6.46 & 0.97 & 0.66 & -11.08 & -0.02 & N\# & 0.68 \\
\hline & 9.3 & 0.8 & 3.0 & -9.1 & 2.9 & 3.4 & & 8.2 & 1.5 & 1.4 & -7.9 & 4.0 & 0.0 & & 6.5 & 0.5 & 3.4 & -9.9 & 3.3 & 3.4 & \\
\hline
\end{tabular}

Note: (1) Highlighted estimates indicate statistical significance at $5 \%$ (2) Italicized figures are the values for the associated relevant test statistics (3) \# indicates statistical significance at $10 \%$ 
Table 5: The "neighbourhood" profile of Indian states

\begin{tabular}{|c|c|c|c|c|c|c|c|c|}
\hline State & $\begin{array}{l}\text { Svs share in real } \\
\text { PCY }(\%)\end{array}$ & $\begin{array}{c}\text { Svs share in } \\
\text { employment }(\%)\end{array}$ & $\begin{array}{l}\text { Real PCY (INR, } \\
\text { 2000-07) }\end{array}$ & Contiguous boundary with: & $\begin{array}{l}\text { Number of } \\
\text { neighbours }\end{array}$ & $\begin{array}{c}\text { Rank_Real } \\
\text { PCY }\end{array}$ & $\begin{array}{c}\text { Rank_Svs share in } \\
\text { real PCY }\end{array}$ & $\begin{array}{c}\text { Rank_Svs share in } \\
\text { employment }\end{array}$ \\
\hline $\mathrm{AP}$ & 49.6 & 30.5 & 21157 & $\mathrm{MH}^{*}, \mathrm{CH}, \mathrm{OR}, \mathrm{KN}^{*}, \mathrm{TN}^{*}$ & 5 & 10 & 14 & 18 \\
\hline $\mathrm{AR}$ & 44.0 & 22.9 & 11009 & AS, NA & 2 & 23 & 20 & 24 \\
\hline AS & 48.1 & 31.7 & 1807 & AR, NA, MZ, MA, ME, TR, WB & 7 & 28 & 15 & 15 \\
\hline $\mathrm{BH}$ & 54.8 & 21.1 & 7264 & UP, JH, WB & 3 & 26 & 5 & 27 \\
\hline $\mathrm{CH}$ & 39.2 & 20.5 & 6090 & $\mathrm{UP}, \mathrm{MP}, \mathrm{MH}^{*}, \mathrm{JH}, \mathrm{AP}^{*}, \mathrm{OR}$ & 6 & 27 & 25 & 28 \\
\hline GJ & 37.6 & 30.2 & 25337 & $\mathrm{RJ}, \mathrm{MP}, \mathrm{MH}^{*}$ & 3 & 7 & 28 & 19 \\
\hline GO & 47.1 & 64.6 & 49331 & $\mathrm{MH}^{*}, \mathrm{KN}^{*}$ & 2 & 1 & 16 & 1 \\
\hline HP & 38.0 & 33.3 & 28531 & JK, PJ*, HR*, UP, UT & 5 & 4 & 27 & 13 \\
\hline HR & 41.9 & 41.5 & 29325 & PJ*, RJ, HP*, UT, TP & 5 & 3 & 24 & 6 \\
\hline $\mathrm{JH}$ & 38.3 & 29.1 & 14281 & $\mathrm{BH}, \mathrm{WB}, \mathrm{OR}, \mathrm{CH}, \mathrm{UP}$ & 5 & 19 & 26 & 20 \\
\hline $\mathrm{JK}$ & 46.4 & 40.8 & 16570 & $\mathrm{HP}^{*}, \mathrm{PJ}^{*}$ & 2 & 16 & 17 & 7 \\
\hline $\mathrm{KN}$ & 51.1 & 27.7 & 21477 & $\mathrm{GO}^{*}, \mathrm{MH}^{*}, \mathrm{AP}^{*}, \mathrm{TN}^{*}, \mathrm{KR}^{*}$ & 5 & 9 & 11 & 22 \\
\hline $\mathrm{KR}$ & 59.4 & 50.5 & 26547 & $\mathrm{TN}^{*}, \mathrm{KN}^{*}$ & 2 & 6 & 2 & 3 \\
\hline MA & 43.1 & 30.6 & 16452 & NA, MZ, AS & 3 & 17 & 21 & 17 \\
\hline ME & 51.3 & 21.7 & 19071 & AS & 1 & 14 & 10 & 26 \\
\hline MH & 58.7 & 35.3 & 28163 & $\mathrm{GO}^{*}, \mathrm{GJ}^{*}, \mathrm{MP}, \mathrm{CH}, \mathrm{AP}^{*}, \mathrm{KN}^{*}$ & 6 & 5 & 3 & 9 \\
\hline MP & 49.6 & 22.3 & 13208 & UP, RJ, GJ*, MH*, CH & 5 & 20 & 13 & 25 \\
\hline MZ & 64.4 & 31.8 & 20071 & TR, AS, MA & 3 & 11 & 1 & 14 \\
\hline NA & 53.9 & 40.6 & 18407 & $\mathrm{AR}, \mathrm{AS}, \mathrm{MA}$ & 3 & 15 & 6 & 8 \\
\hline OR & 45.1 & 24.0 & 7424 & $\mathrm{JH}, \mathrm{WB}, \mathrm{CH}, \mathrm{AP}^{*}$ & 4 & 25 & 18 & 23 \\
\hline PJ & 42.5 & 44.8 & 30486 & JK, HP* RJ, HR* & 4 & 2 & 23 & 4 \\
\hline $\mathrm{RJ}$ & 42.9 & 31.2 & 16152 & $\mathrm{PJ}^{*}, \mathrm{HR}^{*}, \mathrm{UP}, \mathrm{MP}, \mathrm{GJ}^{*}$ & 5 & 18 & 22 & 16 \\
\hline SI & 52.1 & 43.6 & 13033 & WB & 1 & 21 & 9 & 5 \\
\hline $\mathrm{TN}$ & 56.8 & 34.4 & 24937 & $\mathrm{AP}^{*}, \mathrm{KN}^{*}, \mathrm{KR}^{*}$ & 3 & 8 & 4 & 11 \\
\hline TR & 52.8 & 57.2 & 10949 & $\mathrm{AS}, \mathrm{MZ}$ & 2 & 24 & 8 & 2 \\
\hline UP & 44.7 & 29.0 & 11291 & UT, HR*, RJ, MP, CH, JH, BH & 7 & 22 & 19 & 21 \\
\hline UT & 49.8 & 33.9 & 19657 & $\mathrm{HP}^{*}, \mathrm{HR}^{*}, \mathrm{UP}$ & 3 & 13 & 12 & 12 \\
\hline WB & 53.5 & 34.9 & 19790 & OR, JH, BH, SI, AS & 5 & 12 & 7 & 10 \\
\hline
\end{tabular}

Note: * indicates rich neighbour [top 10 in terms of real per capita income] 
Table 6: Decomposing external demand - from neighbours and rest of India

\begin{tabular}{|c|c|c|c|c|c|c|c|c|c|c|c|c|c|c|c|c|c|c|c|c|c|c|c|c|}
\hline \multirow[b]{2}{*}{ State } & \multicolumn{8}{|c|}{ mmm DGLS, original data mmmmmm } & \multicolumn{8}{|c|}{ mmm } & \multicolumn{8}{|c|}{ 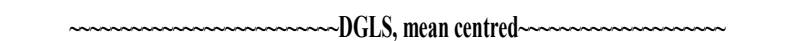 } \\
\hline & Intercept & Intdd & Neighdd & Restdd & Urb & Lib & Restdd=Neighdd & Abs(restdd/neighdd) & Intercept & Intdd & Neighdd & Restdd & Urb & Lib & Restdd=Neighdd & Abs(restdd/neighdd) & Intercept & Intdd & Neighdd & Restdd & Urb & Lib & Restdd=Neighdd & Abs(restdd/neighdd) \\
\hline \multirow[t]{2}{*}{ AP } & -0.79 & 1.08 & -0.59 & 0.08 & 0.92 & -0.17 & $\mathrm{~N}$ & 0.13 & -7.26 & 1.13 & -0.50 & 0.65 & 1.47 & -0.21 & $\mathrm{~N}$ & 1.31 & 6.36 & 1.18 & -0.57 & 0.01 & 0.89 & -0.20 & $\mathrm{~N}$ & 0.03 \\
\hline & -0.9 & 10.6 & -6.4 & 0.6 & 4.1 & -3.5 & 8.9 & & -11.2 & 12.4 & -5.8 & 5.6 & 7.1 & -4.9 & 39.6 & & 516.3 & 11.8 & -6.2 & 0.1 & 3.8 & -4.1 & 8.9 & \\
\hline \multirow[t]{2}{*}{ BH } & 0.83 & 1.72 & -0.61 & -0.44 & -1.17 & 0.17 & $\mathrm{~N}$ & 0.73 & -0.10 & 1.64 & -0.49 & 0.17 & -1.37 & 0.20 & $\mathrm{~N}$ & 0.35 & 5.12 & 1.77 & -0.57 & -0.47 & -1.06 & 0.17 & $\mathrm{~N}$ & 0.83 \\
\hline & 1.1 & 4.5 & -0.2 & -3.4 & -7.0 & 5.4 & 4.0 & & 5.5 & 3.6 & 0.1 & -3.2 & -9.6 & 6.9 & 4.1 & & -82.3 & 4.1 & 0.1 & -3.1 & -6.2 & 5.9 & 4.0 & \\
\hline \multirow[t]{2}{*}{ GJ } & 2.60 & 0.12 & -0.24 & 0.69 & 0.02 & -0.44 & Y & 2.87 & -7.20 & 0.15 & -0.16 & 0.77 & 2.45 & -0.34 & Y & 4.77 & 6.43 & 0.11 & -0.21 & 0.59 & 0.48 & -0.44 & Y & 2.83 \\
\hline & 2.3 & -7.7 & 2.9 & 2.3 & -1.1 & -3.3 & 0.5 & & 0.0 & -8.0 & 2.7 & 0.4 & 1.0 & -1.4 & 0.4 & & 2.5 & -8.7 & 3.1 & 2.1 & -0.5 & -3.0 & 0.5 & \\
\hline \multirow[t]{2}{*}{ HR } & 1.50 & 0.36 & -0.21 & 0.26 & 0.49 & -0.02 & $\mathrm{Y}$ & 1.23 & -4.24 & 0.68 & -0.14 & 0.47 & 0.92 & 0.02 & $\mathrm{N \#}$ & 3.45 & 6.66 & 0.43 & -0.20 & 0.28 & 0.37 & -0.02 & Y & 1.41 \\
\hline & 2.9 & -4.8 & 3.0 & 0.6 & -0.6 & 3.0 & 0.1 & & 3.9 & -2.8 & 2.8 & -0.6 & -0.7 & 4.8 & 3.1 & & 5.0 & -4.7 & 2.9 & 0.9 & -0.7 & 3.5 & 0.1 & \\
\hline \multirow[t]{2}{*}{ KN } & 0.31 & 0.59 & -0.34 & 0.54 & 0.03 & -0.06 & $\mathrm{Y}$ & 1.57 & -12.39 & 0.05 & -0.13 & 1.03 & 3.51 & -0.14 & $\mathrm{Y}$ & 7.88 & 6.39 & 0.40 & -0.26 & 0.64 & 0.56 & $-0.10 \#$ & Y & 2.43 \\
\hline & 1.3 & -4.6 & 2.7 & 3.5 & -2.7 & 2.3 & 2.2 & & -4.8 & -9.0 & 3.7 & 2.6 & 4.4 & 1.6 & 0.0 & & 1.3 & -6.9 & 3.3 & 4.3 & -0.9 & 1.9 & 2.2 & \\
\hline \multirow[t]{2}{*}{ KR } & -0.29 & -1.55 & -0.54 & 3.26 & -0.28 & -0.39 & $\mathrm{~N}$ & 6.00 & -5.26 & -1.65 & -0.13 & 3.60 & -0.01 & -0.48 & $\mathrm{~N}$ & 28.20 & 6.82 & -1.45 & -0.67 & 3.34 & -0.22 & -0.40 & $\mathrm{~N}$ & 4.99 \\
\hline & 0.7 & -16.8 & 0.3 & 13.2 & -5.4 & -3.7 & 100.4 & & 2.9 & -15.9 & 2.5 & 11.0 & -7.1 & -4.4 & 46.7 & & 24.3 & -16.3 & -0.7 & 13.6 & -4.8 & -3.2 & 100.4 & \\
\hline \multirow[t]{2}{*}{ MP } & -16.40 & -0.15 & -1.00 & -0.90 & 10.47 & -0.42 & $\mathrm{~N}$ & 0.90 & -1.13 & 1.3\# & 0.24 & 0.65 & -2.64 & -0.04 & $\mathrm{~N}$ & 2.75 & 5.47 & 1.31 & 0.29 & 0.66 & -4.88 & -0.04 & $\mathrm{Y}$ & 2.27 \\
\hline & 1.6 & 2.2 & 3.8 & 1.3 & -3.8 & 2.8 & 0.8 & & 6.2 & 1.7 & 3.5 & 0.0 & -2.9 & 3.8 & 10.6 & & -28.6 & 1.3 & 4.1 & 1.9 & -4.0 & 3.2 & 0.8 & \\
\hline \multirow[t]{2}{*}{ MH } & 1.50 & 1.31 & 0.17 & 0.50 & -4.12 & -0.03 & $Y$ & 2.96 & -27.10 & -0.13 & -0.98 & -0.89 & 13.40 & -0.42 & $\mathrm{~N}$ & 0.91 & 6.82 & -0.10 & -0.95 & -0.98 & 10.51 & -0.39 & $\mathrm{~N}$ & 1.03 \\
\hline & -6.9 & -8.1 & -2.6 & -7.0 & 8.5 & -2.6 & 6.4 & & -9.2 & -8.7 & -3.1 & -11.9 & 11.1 & -2.3 & 21.3 & & 11.5 & -8.6 & -2.4 & -7.0 & 8.7 & -2.0 & 6.4 & \\
\hline \multirow[t]{2}{*}{ OR } & 2.13 & 0.35 & -0.16 & 0.45 & $-0.7 \#$ & 0.10 & $\mathrm{Y}$ & 2.77 & -3.64 & 0.28 & -0.42 & 1.05 & 0.85 & 0.10 & $\mathrm{Y}$ & 2.49 & 5.35 & 0.40 & $\begin{array}{l}-0.19 \\
\end{array}$ & 0.36 & -0.27 & 0.10 & $\mathrm{Y}$ & 1.92 \\
\hline & 3.4 & -3.8 & 1.3 & 0.9 & -1.9 & 5.4 & 0.0 & & 4.3 & -4.2 & 0.2 & 0.9 & -0.6 & 6.2 & 0.2 & & -15.5 & -3.9 & 1.2 & 0.8 & -1.3 & 5.8 & 0.0 & \\
\hline \multirow[t]{2}{*}{ PJ } & 5.24 & 0.90 & -0.13 & -0.21 & -0.92 & 0.10 & $\mathrm{~N}$ & 1.59 & -1.80 & 1.59 & -0.10 & -0.19 & -0.45 & 0.10 & $\mathrm{~N}$ & 1.80 & 7.00 & 1.25 & -0.18 & -0.18 & -1.75 & 0.12 & N\# & 0.96 \\
\hline & 5.5 & -0.6 & 4.0 & -1.1 & -2.3 & 4.8 & 3.3 & & 7.4 & 3.2 & 4.1 & -5.1 & -4.6 & 6.8 & 26.9 & & 29.5 & 0.3 & 3.5 & -0.8 & -3.7 & 5.8 & 3.3 & \\
\hline \multirow[t]{2}{*}{ RJ } & -23.02 & 0.30 & -0.49 & -0.98 & 11.77 & 0.40 & $\mathrm{~N}$ & 2.02 & -29.00 & 0.27 & -0.16 & -0.48 & 11.99 & 0.35 & $\mathrm{~N}$ & 3.06 & 6.05 & 0.23 & -0.42 & -1.00 & 12.16 & 0.39 & $\mathrm{~N}$ & 2.41 \\
\hline & -8.6 & -5.5 & 0.7 & -4.4 & 8.9 & 8.2 & 13.0 & & -8.0 & -6.1 & 2.4 & -4.6 & 8.3 & 8.3 & 18.5 & & -12.9 & -6.6 & 1.2 & -4.4 & 9.9 & 8.9 & 13.0 & \\
\hline \multirow[t]{2}{*}{$\mathrm{TN}$} & 3.74 & 1.08 & -0.80 & 0.00 & 0.14 & -0.12 & Y & 0.01 & -1.32 & 1.06 & -0.59 & 0.72 & -0.19 & -0.10 & Y & 1.21 & 6.55 & 1.02 & -0.71 & 0.08 & 0.02 & $-0.11 \#$ & Y & 0.12 \\
\hline & 6.4 & 0.0 & -2.2 & -0.6 & -3.3 & 1.0 & 1.2 & & 8.8 & -0.7 & -0.9 & 0.5 & -7.5 & 2.5 & 0.7 & & 13.9 & -1.6 & -1.5 & 0.6 & -3.7 & 1.8 & 1.2 & \\
\hline \multirow[t]{2}{*}{ UP } & (omitted) & 0.73 & 0.26 & -0.47 & -0.35 & 0.34 & $\mathrm{~N}$ & 1.80 & -4.30 & 0.86 & 0.39 & -0.24 & 1.07 & 0.11 & $\mathrm{~N}$ & 0.62 & 5.51 & 0.71 & 0.23 & -0.44 & $0.14 \#$ & 0.40 & $\mathrm{~N}$ & 1.93 \\
\hline & & -3.11 & 7.86 & -4.14 & -2.69 & 5.73 & 38.3 & & 2.7 & -2.9 & 9.1 & -7.6 & -1.1 & 4.9 & 82.5 & & -31.5 & -4.53 & 7.87 & -3.66 & -1.77 & 8.05 & 38.3 & \\
\hline \multirow[t]{2}{*}{ WB } & 30.98 & 0.81 & 0.48 & 0.17 & -10.64 & 0.04 & $\mathrm{~N}$ & 0.36 & 7.15 & 1.14 & 0.41 & 0.17 & -3.90 & 0.07 & $\mathrm{~N}$ & 0.41 & 6.44 & 0.80 & 0.55 & 0.18 & -10.08 & 0.05 & $\mathrm{~N}$ & 0.33 \\
\hline & 13.7 & -2.2 & 9.4 & 0.6 & -13.4 & 4.1 & 19.6 & & 8.5 & 0.0 & 9.6 & -3.4 & -8.8 & 6.2 & 47.5 & & 5.0 & -3.2 & 10.4 & 1.0 & -12.9 & 5.1 & 19.6 & \\
\hline
\end{tabular}

Note: (1) Highlighted estimates indicate statistical significance at 5\% (2) Italicized figures are the values for the associated relevant test statistics (3) \# indicates statistical significance at 10\% 
Table A1: Results from unit root tests on common factor and error

\begin{tabular}{llllcll}
\hline & $\begin{array}{l}\text { Xit } \\
\text { defined } \\
\text { on: }\end{array}$ & $\begin{array}{c}\text { Variation in Xit } \\
\text { explained by common } \\
\text { factor (\%) }\end{array}$ & $\begin{array}{c}\text { ADF on } \\
\text { common factor }\end{array}$ & $\begin{array}{c}\text { ADF } \\
\text { on } \\
\text { error }\end{array}$ & $\begin{array}{c}\text { DFGLS on } \\
\text { common factor }\end{array}$ & Comment \\
Major states, 1980-2006 & PCY & 26.3 & -8.9 & -9.2 & -9.1 & C \\
Major states, 1980-2006 & PCSER & 46 & -5.4 & -5.6 & -5.6 & C \\
Major states, 1990-2006 & PCY & 33.7 & -4.9 & -5.1 & -5.5 & C \\
Major states, 1990-2006 & PCSER & 61 & -4.0 & -4.2 & -4.3 & C \\
\hline
\end{tabular}

Note: (1) Optimal lag length from Ng-Perron for all tests was 0 (2) 'C' stands for convergence (3) ADF critical values for all samples at 1,5 and $10 \%$ were $-3.75,-3.0$ and -2.63 , respectively (4) DFGLS critical values at 1,5 and $10 \%$ were: -3.77 , 3.45 and -3.1 for major states over 1980-2006; and -3.77, -3.64 and -3.2 over 1990-2006.

Table A2: Results from Breitung \& Das (2005) panel unit root tests

\begin{tabular}{llccc} 
& \multicolumn{2}{c}{ Without trend } & \multicolumn{2}{c}{ With trend } \\
Series & $\lambda^{*}$ & p-value & $\lambda^{*}$ & p-value \\
lpcser & 1.4 & 0.92 & -0.06 & 0.48 \\
lpcintdd & 1.6 & 0.95 & 0.24 & 0.6 \\
lpcextdd & 1.5 & 0.93 & 1.36 & 0.9 \\
llib & -1.4 & 0.086 & 0.26 & 0.6 \\
lurb & -0.33 & 0.37 & -1.14 & 0.13
\end{tabular}

Note: The test was conducted with a lag length of 5 for all series. 
Table A3: Results from ADF unit root tests

\begin{tabular}{|c|c|c|c|c|c|c|c|c|c|c|c|c|c|c|c|c|}
\hline Variables & $\mathbf{A P}$ & BH & GJ & GO & HP & HR & $\mathbf{K N}$ & $\mathbf{K R}$ & МH & MP & OR & PJ & RJ & $\mathbf{T N}$ & UP & WB \\
\hline LPCSER & $\mathrm{I}(1)^{*}$ & $\mathrm{I}(1) * * *$ & $\mathrm{I}(1) * * *$ & $\mathrm{I}(1)^{* * *}$ & $\mathrm{I}(1)^{* *}$ & $\mathrm{I}(1)^{* * *}$ & $\mathrm{I}(1)^{* *}$ & $\mathrm{I}(1) * * *$ & $\mathrm{I}(1) * * *$ & $\mathrm{I}(1) * * *$ & $\mathrm{I}(1)^{* * *}$ & $\mathrm{I}(1)^{* *}$ & $\mathrm{I}(1) * * *$ & $\mathrm{I}(1)^{* * *}$ & $\mathrm{I}(1) * * *$ & $\mathrm{I}(2)^{* * *}$ \\
\hline LPCINTDD(-1) & $\mathrm{I}(0)^{*}$ & $\mathrm{I}(1)^{* * *}$ & $\mathrm{I}(0)^{*}$ & $\mathrm{I}(1)^{* *}$ & $\mathrm{I}(1)^{* *}$ & $\mathrm{I}(1)^{* * *}$ & $\mathrm{I}(1)^{* * *}$ & $\mathrm{I}(1)^{* * *}$ & $\mathrm{I}(1) * * *$ & $\mathrm{I}(1) * * *$ & $\mathrm{I}(0)^{*}$ & $\mathrm{I}(0)^{*}$ & $\mathrm{I}(1) * * *$ & $\mathrm{I}(1)^{* * *}$ & $\mathrm{I}(1) * * *$ & $\mathrm{I}(1)^{* * *}$ \\
\hline LPCEXTDD(-1) & $\mathrm{I}(1)^{* * *}$ & $\mathrm{I}(2)^{* * *}$ & $\mathrm{I}(1)^{*}$ & $\mathrm{I}(2) * * *$ & $\mathrm{I}(2)^{* * *}$ & $\mathrm{I}(1)^{* * *}$ & $\mathrm{I}(1)^{* * *}$ & $\mathrm{I}(1)^{* * *}$ & $\mathrm{I}(1) * * *$ & $\mathrm{I}(1)^{* * *}$ & $\mathrm{I}(1)^{* * *}$ & $\mathrm{I}(1)^{* * *}$ & $\mathrm{I}(1)^{* * *}$ & $\mathrm{I}(1)^{* * *}$ & $\mathrm{I}(0)^{*}$ & $\mathrm{I}(1)^{* * *}$ \\
\hline LPCNEIGHDD(-1) & $\mathrm{I}(0)^{* *}$ & $\mathrm{I}(1)^{* * *}$ & $\mathrm{I}(1)^{* * *}$ & $\mathrm{I}(1)^{* * *}$ & $\mathrm{I}(0) * * *$ & $\mathrm{I}(1)^{* * *}$ & $\mathrm{I}(0)^{* *}$ & $\mathrm{I}(1)^{* * *}$ & $\mathrm{I}(1) * * *$ & $\mathrm{I}(1)^{* *}$ & $\mathrm{I}(1) * * *$ & $\mathrm{I}(0)^{*}$ & $\mathrm{I}(1)^{* * *}$ & $\mathrm{I}(1)^{* * *}$ & $\mathrm{I}(1) * * *$ & $\mathrm{I}(1)^{* * *}$ \\
\hline LPCRESTDD(-1) & $\mathrm{I}(1)^{*}$ & $\mathrm{I}(1)^{* * *}$ & $\mathrm{I}(1) * * *$ & $\mathrm{I}(2)^{* * *}$ & & $\mathrm{I}(1)^{* * *}$ & $\mathrm{I}(1)^{* * *}$ & $\mathrm{I}(1)^{* * *}$ & $\mathrm{I}(0) * * *$ & $\mathrm{I}(1)^{* * *}$ & $\mathrm{I}(1) * * *$ & $\mathrm{I}(1)^{* * *}$ & $\mathrm{I}(1)^{* * *}$ & $\mathrm{I}(1)^{* * *}$ & $\mathrm{I}(1) * * *$ & $\mathrm{I}(0)^{* *}$ \\
\hline LLIB & $\mathrm{I}(1)^{* * *}$ & $\mathrm{I}(0) * *$ & $\mathrm{I}(0)^{* *}$ & & & $\mathrm{I}(1)^{* * *}$ & $\mathrm{I}(0)^{* * *}$ & $\mathrm{I}(0) * *$ & $\mathrm{I}(0) * * *$ & $\mathrm{I}(0)^{*}$ & $\mathrm{I}(1) * * *$ & $\mathrm{I}(1)^{* * *}$ & $\mathrm{I}(0)^{*}$ & $\mathrm{I}(1)^{* * *}$ & $\mathrm{I}(0)^{*}$ & $\mathrm{I}(0)^{* *}$ \\
\hline LURB & $\mathrm{I}(0) * *$ & $\mathrm{I}(2)^{* * *}$ & $\mathrm{I}(1)^{* * *}$ & & $\mathrm{I}(1)^{* * *}$ & $\mathrm{I}(1)^{* * *}$ & $\mathrm{I}(1)^{*}$ & $\mathrm{I}(0) * *$ & $\mathrm{I}(1)^{* * *}$ & $\mathrm{I}(0)^{* *}$ & $\mathrm{I}(0)^{* *}$ & $\mathrm{I}(2)^{* * *}$ & $\mathrm{I}(1)^{*}$ & $\mathrm{I}(2)^{* * *}$ & $\mathrm{I}(1)^{*}$ & $\mathrm{I}(1)^{* * *}$ \\
\hline
\end{tabular}

Note: $* * *$ and $* * *$ indicate $10 \%, 5 \%$ and $1 \%$ levels of significance, respectively.

Table A4: Results from Johansen-Juselius (J-J) Cointegration Tests

\begin{tabular}{|c|c|c|c|c|c|c|c|c|c|c|c|c|c|c|}
\hline No. of cointegrating equations & $\mathbf{A P}$ & BH & GJ & HR & $\mathbf{K N}$ & $\mathbf{K R}$ & MH & MP & OR & $\mathbf{P J}$ & RJ & $\mathbf{T N}$ & $\mathbf{U P}$ & WB \\
\hline J-J TEST (Trace)\# & $6 * *$ & $4 * *$ & $5 * *$ & $4 * *$ & $3 * *$ & $4 * *$ & $4 * *$ & $3 * *$ & $3 * *$ & $3 * *$ & $4 * *$ & $5 * *$ & $4 * *$ & $6^{* *}$ \\
\hline J-J TEST (Trace)\#\# & $5^{*}$ & $3 *$ & $4 *$ & $3 *$ & $3 *$ & $3 *$ & $3 *$ & $2 *$ & $3 *$ & $3 *$ & $3 *$ & $4^{*}$ & $4 *$ & $4 *$ \\
\hline J-J TEST (Max eigenvalue)\# & $6 * *$ & $3 * *$ & $5 * *$ & $2 * *$ & $2 * *$ & $2 * *$ & $4 * *$ & $2 * *$ & $3 * *$ & $3 * *$ & $4 * *$ & $5 * *$ & $4 * *$ & $3 * *$ \\
\hline J-J TEST (Max eigenvalue)\#\# & $3 *$ & $2 *$ & $2 *$ & $2 *$ & $2 *$ & $2 *$ & $3 *$ & $2 *$ & $3 *$ & $3 *$ & $3^{*}$ & $4^{*}$ & $2 *$ & $2 *$ \\
\hline
\end{tabular}

Note: $(1) *$ and $* *$ indicate $10 \%$ and $5 \%$ levels of significance, respectively (2) \# indicates primary regression (equation 1); \#\# indicates secondary regression (equation 2 ) 